\title{
Apatite Composition: Tracing Petrogenetic Processes in Transhimalayan Granitoids
}

\section{MEI-FEI GHU ${ }^{1,2,3} *$, KUO-LUNG WANG ${ }^{2}$, WILLIAM L. GRIFFIN ${ }^{3}$, SUN-LIN GHUNG ${ }^{1}$, SUZANNE Y. O'REILLY ${ }^{3}$, NORMAN J. PEARSON ${ }^{3}$ AND YOSHIYUKI IIZUKA ${ }^{2}$}

\author{
${ }^{1}$ DEPARTMENT OF GEOSGIENGES, NATIONAL TAIWAN UNIVERSITY, TAIPEI 10699, TAIWAN \\ ${ }^{2}$ INSTITUTE OF EARTH SCIENCES, ACADEMIA SINICA, TAIPEI 11529, TAIWAN \\ ${ }^{3}$ ARG NATIONAL KEY CENTRE FOR GEOCHEMICAL EVOLUTION AND METALLOGENY OF CONTINENTS (GEMOG), \\ DEPARTMENT OF EARTH AND PLANETARY SGIENGES, MACQUARIE UNIVERSITY, SYDNEY, NSW 2109, AUSTRALIA
}

REGEIVED JULY 9, 2008; ACGEPTED JULY 28, 2009

\begin{abstract}
Apatites crystallized from different types of igneous rocks show significant variations in the abundances of some minor and trace elements. In this study, electron probe microanalysis and laser ablation inductively coupled plasma mass spectrometry were used to determine the concentrations of 25 minor and trace elements in apatite separated from three principal rock types of the Transhimalayan igneous plutonic suite: S-type granites, the I-type Gangdese batholith and postcollisional adakites. F, Mn, Sr and rare earth elements (REE) in apatite vary systematically with the composition of the host magma and thus have high potential as petrogenetic tracers. More specifically, the F and Mn contents of apatite can be used as an indicator of magma aluminosity or differentiation index. Combined with $\mathrm{Sr}$ and REE data, which show significant variations in apatite from different rock types, these elements are useful for constructing 'discrimination diagrams.' This study also reveals that apatite has the capacity to retain geochemical information about the host magma through the course of magmatic evolution. Systematic variations of Sr and REE in apatite with bulk-rock aluminosity are the results of partition competition with pre-existing and coexisting major and accessory minerals in silicate melts, and thus are useful for more detailed investigations of petrogenetic processes such as fractional crystallization and magma mixing, which is signaled by inconsistent Eu anomalies, Sr abundances and REE patterns relative to bulkrock compositions.
\end{abstract}

KEY WORDS: apatite; apatite minor elements; apatite trace elements; igneous petrogenesis

*Corresponding author. Telephone: +61 29850 6125. Fax: +61 29850 6904. E-mail: mchu@els.mq.edu.au

\section{N T RODUCTION}

Though tiny and sparse, accessory minerals that concentrate various geologically significant trace elements can provide critical constraints on the details of igneous processes in magma chambers. The rapid recent progress in micro-analytical techniques (e.g. laser ablation inductively coupled plasma mass specrometry; LA-ICP-MS) allows their in situ geochemical analysis and further application in igneous petrogenesis. This type of microanalysis can provide information that is not accessible through conventional bulk-rock analysis. For example, zircon, a common accessory mineral, has been intensively used to study magma evolution, the assembly of magma chambers and crustal growth history by in situ analysis of hafnium or oxygen isotopes, sometimes combined with $\mathrm{U}-\mathrm{Th}-\mathrm{Pb}$ age determinations and trace element patterns (e.g. Schärer et al., 1997; Griffin et al., 2000, 2002; Wilde et al., 2001; Valley, 2003; Belousova et al., 2006; Hawkesworth \& Kemp, 2006; Kemp et al., 2007).

Apatite, although less intensively studied, may be the next candidate for such expanded application. In terms of its common occurrence, stability during magma evolution and chemical diversity, apatite is comparable with zircon and even better in some respects. Apatite is an early crystallizing and long-lasting phase that reaches saturation during the evolution of a range of silicate melts (Hoskin et al., 2000). In situ Sr-isotope analyses (Bizzarro et al.,

(C) The Author 2009. Published by Oxford University Press. All rights reserved. For Permissions, please e-mail: journals.permissions@ oxfordjournals.org 


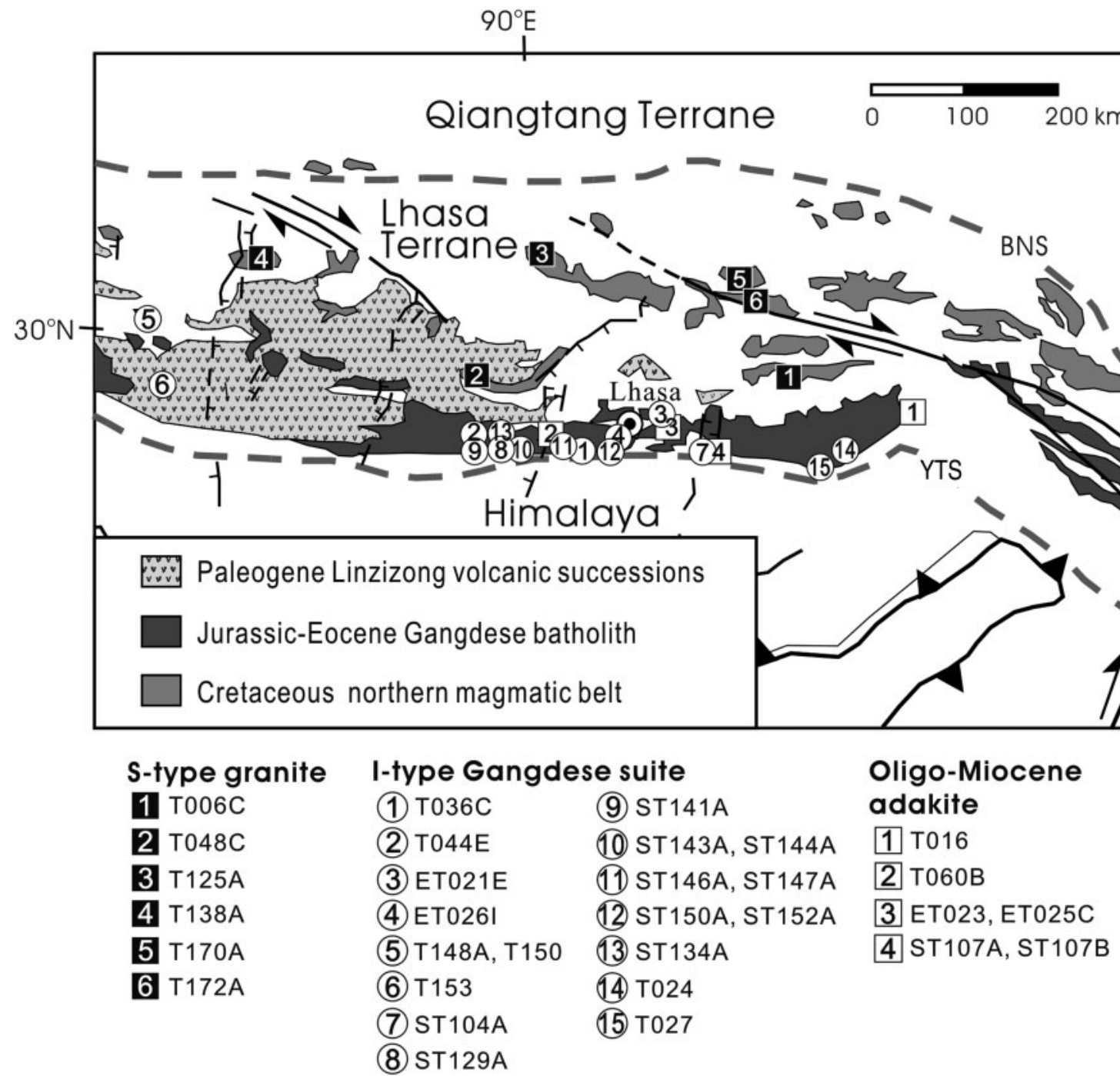

Fig. 1. Simplified geological map showing sample localities and the distribution of major magmatic suites in the Transhimalayan domain of southern Tibet (after Chung et al., 2003). BNS, Bangong-Nujiang suture; YTS, Yarlung-Tsangpo suture.

2003) and $\mathrm{U}-\mathrm{Th}-\mathrm{Pb}$ dating (Sano et al., 1999; Willigers et al., 2002) of apatite have shown preliminary success. More specifically, the minor- and trace-element patterns of apatites vary with their host-rock type, particularly the aluminosity (Bea, 1996; Sha \& Chappell, 1999; Belousova et al., 2001, 2002; Hsieh et al., 2008), and thus detrital apatite has potential as a provenance indicator in sedimentary rocks.

There are two major sources of data on minor- and trace-element abundances in apatite in plutonic rocks. Sha \& Chappell (1999) reported minor- and trace-element compositions of apatite from 'classical' I- and S-type granitoids $\left(\mathrm{SiO}_{2}>57 \mathrm{wt} \%\right)$ from the Lachlan Fold Belt, eastern Australia, and interpreted the data in terms of fractional crystallization, redox conditions, ionic substitution and mineral competition. Belousova et al. (2002) classified apatite compositions in terms of their host-rock chemistry, including the variable silica contents of granitoids. To understand the relationships between magmatic processes and the geochemical characteristics of apatite, apatites from a range of Transhimalayan plutonic rocks have been analysed in this study (Fig. 1). The geochemical composition of apatite from post-collisional adakites (Chung et al., 2003) is reported for the first time, and apatites from the I-type Gangdese magmatic suite, with $\mathrm{SiO}_{2}$ contents ranging from 52 to $74 \mathrm{wt} \%$ (Table 1), are interpreted in terms of magma evolution during fractional crystallization. Integration of these data, comparing them with the geochemical compositions of their host-rocks and the Hfisotope composition of zircon in the same host-rocks, allows an evaluation of the usefulness of apatite geochemistry in studies of igneous processes. 


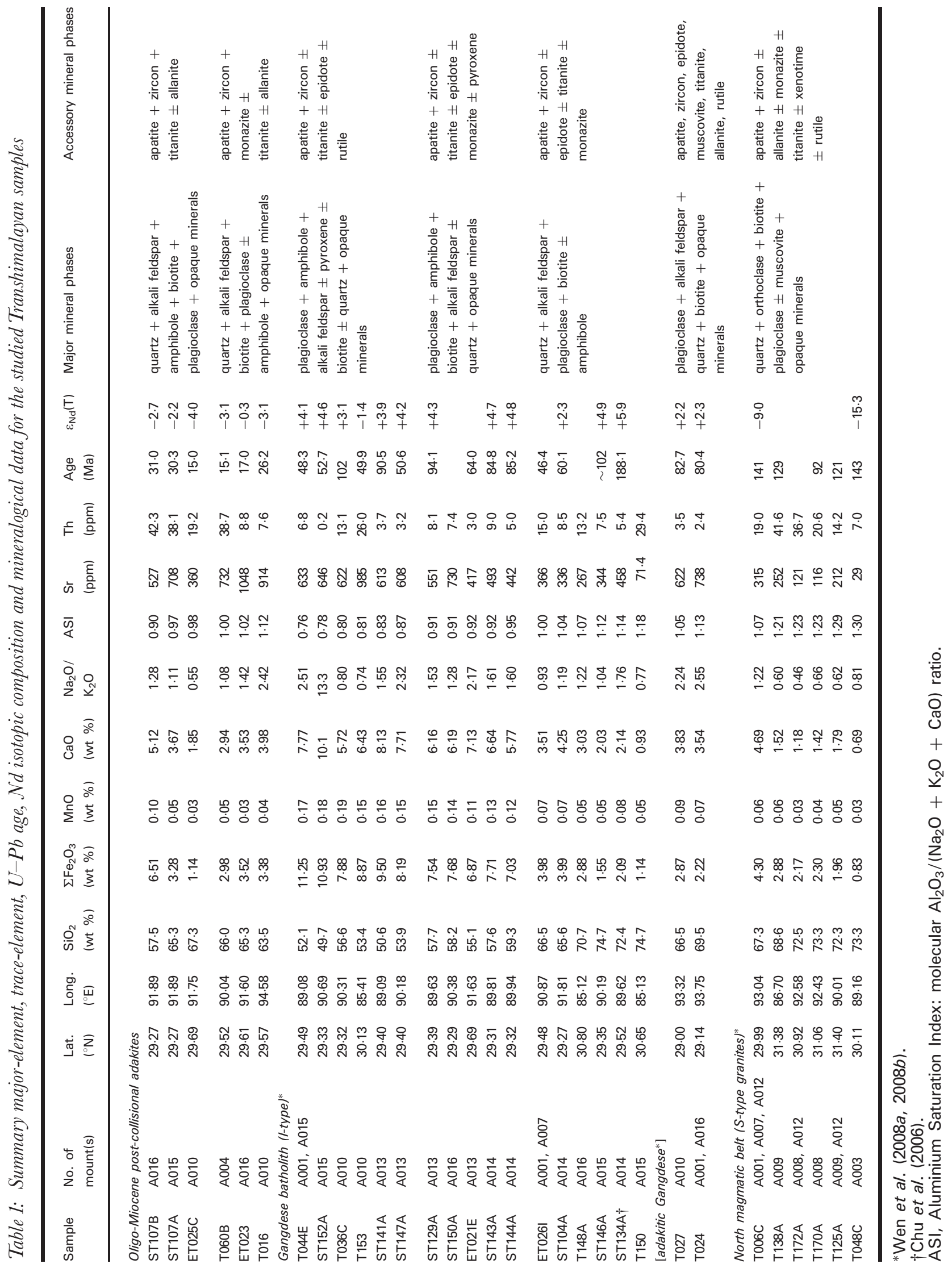




\section{GEOLOGIGAL BAGKGROUND AND SAMPLES}

The continental collision between India and Asia starting in the early Cenozoic resulted in the rise of the Tibetan plateau and the Himalayas (Molnar \& Tapponnier, 1975). Tibet is a tectonic collage of three east-west-trending Gondwana-derived continental fragments; from north to south, these are the Songpan-Ganze, Qiangtang and Lhasa terranes (Fig. 1), sequentially accreted to Asia during the Paleozoic to early Cenozoic (Allègre et al., 1984). The Lhasa terrane, the so-called Transhimalaya, bounds the southernmost part of Asia and contacts with India along the Yarlung-Tsangpo suture zone, which is the relic of the Neo-Tethys Ocean that existed before the India-Asia collision (Yin \& Harrison, 2000).

The Lhasa terrane consists primarily of Paleozoic to Mesozoic sedimentary rocks associated with MesozoicCenozoic igneous rocks (Pan et al., 2004). The latter may be categorized into three principal rock types according to their geochemistry and/or occurrence (Fig. 1): (1) S-type granites in the northern magmatic belt, (2) I-type granitoids of the Gangdese batholith in the south; (3) postcollisional adakites that occur as small plugs or sills cutting across the Gangdese batholith (Table 1). For this study, apatite was separated from representative samples of each of these three suites.

\section{S-type granites: the northern magmatic belt}

The northern magmatic belt is located in the northern part of the Lhasa terrane (Fig. 1) and is largely composed of Early Cretaceous (c. 150-120 Ma) peraluminous or S-type granitoids (Xu et al., 1985; Harris et al., 1990; Pan et al., 2004). These rocks have evolved compositions with 67-73 wt $\% \mathrm{SiO}_{2}$ and negative $\varepsilon_{\mathrm{Nd}}(\mathrm{T})$ values (Table 1), indicating derivation largely from the remelting of older crust. Their main mineral constituents are quartz + alkali feldspar + plagioclase + biotite + opaque minerals, associated with accessory phases including apatite + zircon \pm allanite \pm monazite \pm titanite \pm xenotime (Table 1) Although zircon appears to be a common accessory mineral, most of the zircon in these rocks is inherited (see Chu et al., 2006).

There has been a long-term debate about the petrogenesis of the northern magmatic belt (see Kapp et al., 2005); this has been attributed to: (1) crustal anatexis during the continental collision of the Lhasa-Qiangtang terranes (e.g. Xu et al., 1985); (2) high-temperature crustal melting related to asthenospheric upwelling after the LhasaQiangtang terrane collision (e.g. Harris et al., 1990); (3) low-angle northward subduction of the Neo-Tethyan oceanic slab (e.g. Coulon et al., 1986). Our recent work (Chu et al., 2006), which first identified the existence of
Jurassic-age Gangdese magmatism, lends supports to the third tectonic interpretation.

\section{I-type granitoids: the Gangdese batholiths}

The Gangdese batholith belt extends through most of the southern Lhasa terrane. Its occurrence has been widely attributed to northward subduction of Neo-Tethyan oceanic lithosphere beneath the Lhasa terrane. Magmatism took place from Early Jurassic (Chu et al., 2006) to Paleogene times (Wen et al., 2008b, and references therein) and resulted in both the voluminous Gangdese batholith and the associated Linzizong volcanic succession (Allègre et al., 1984; Yin \& Harrison, 2000; Lee et al., 2007, 2009; Wen et al. 2008b; Fig. 1).

The Gangdese batholith consists dominantly of calcalkaline diorite, typical of I-type granitoid compositions (Debon et al., 1986; Wen et al., 2008a, 2008b; Ji et al., 2009; Table 1). However, the Gangdese rocks actually show a wide range of compositions from gabbro to granite. Samples analyzed in this study, for example, have $\mathrm{SiO}_{2}$ contents varying from 50 to $75 \mathrm{wt} \%$ coupled with an $\varepsilon_{\mathrm{Nd}}(\mathrm{T})$ range of -1.4 to +5.9 (Wen, 2007; Wen et al., $2008 a$ ); there is no correlation between silica content and $\mathrm{Nd}$ isotopic composition. With increasing whole-rock silica content the major mineral constituents change from plagioclase \pm amphibole \pm pyroxene \pm biotite \pm alkali feldspar + opaque minerals to quartz + alkali feldspar + biotite + plagioclase \pm amphibole + opaque minerals. Apatite, zircon, titanite and epidote occur as common accessory phases (Table 1).

Wen et al. (2008a) reported the existence of a granodiorite body with adakitic geochemical characteristics, here termed 'adakitic Gangdese' (Table 1), which intruded at $\sim 80 \mathrm{Ma}$ in the southeastern part of the Gangdese batholith. Its petrogenesis was attributed to a stage of flat subduction of the Neo-Tethyan slab.

\section{Post-collisional adakites}

Adakites that were emplaced during Oligo-Miocene time (c. 30-10 Ma) in the southern Lhasa terrane usually occur as small plugs or sills intruding the Gangdese batholith (see Chung et al., 2005). These 'collision-type' adakites show overall geochemical characteristics similar to those of 'normal' adakites formed in modern subduction zones; that is, the rocks are characterized by relative depletions in heavy rare earth elements (HREE) and Y, enrichment in $\mathrm{Sr}$ and thus elevated $\mathrm{Sr} / \mathrm{Y}$. Garnet, which strongly retains HREE, could have been a residual aluminum-rich phase in the sources of the adakites, which therefore have been interpreted as products of partial melting in a collision-thickened mafic lower crust beneath southern Tibet (Chung et al., 2003).

Most of the adakites are of intermediate in composition, with 57-66 wt $\% \quad \mathrm{SiO}_{2}$, and $\varepsilon_{\mathrm{Nd}}(\mathrm{T})$ of -4.0 to -0.3 (Table 1). They are composed of quartz + alkali feldspar 
+ biotite + plagioclase \pm amphibole + opaque minerals, together with apatite + zircon \pm titanite \pm allanite \pm monazite as accessory mineral phases (Table 1).

\section{ANALYTICAL METHODS}

Standard heavy-liquid and magnetic methods were used to obtain pure apatite separates from $\sim 5 \mathrm{~kg}$ rock samples. Apatite grains with no visible inclusions were hand picked under a stereo-microscope, and then mounted in epoxy discs. Most of the Transhimalayan apatites in this study are euhedral to subhedral granular and occasionally hexagonal columnar in shape. Back-scattered electron (BSE) images were taken of some of the apatites (e.g. Gangdese batholith samples: ET021E, ST146A, ST147A, T036C and T153; S-type granites: T006C and T172A); no internal zoning patterns were observed.

\section{Electron probe microanalysis (EPMA)}

Major- and minor-element contents of apatite were determined by electron microprobe at the Institute of Earth Sciences (IES), Academia Sinica, Taiwan, or at GEMOC, Macquarie University, Australia. Up to four spot analyses were performed on each crystal, depending on the grain size. Apatite grains mounted in targets A001 to A006 (Table 1) were analysed using a JEOL JXA-8900R electron microprobe using a wavelength-dispersive (WDS) method that employed TAP, PET, and LIF crystals with $2 \mu \mathrm{m}$ spatial resolution, $15 \mathrm{kV}$ beam conditions and $10 \mathrm{nA}$ beam current. For analysis of apatites in the remaining targets at GEMOC, we used the methods described by Belousova et al. (2002): an electron beam of $10 \mu \mathrm{m}$ diameter with an accelerating voltage of $15 \mathrm{kV}$ and a beam current of 20 $\mathrm{nA}$. Analytical precision for most elements is better than $1 \%$, but for $\mathrm{F}, \mathrm{Cl}$ and $\mathrm{SO}_{3}$ precision is around $5 \%$.

\section{Laser ablation-inductively coupled plasma mass spectrometry (LA-ICPMS)}

The trace-element contents of apatites were measured in the LA-ICP-(Q)MS laboratory in the Department of Geosciences, National Taiwan University, using an Agilent 7500s ICP-MS system and a New Wave LUV213 laser system (Jackson, 2001). Analytical methods, which mainly follow those of Norman et al. $(1996,1998)$ involved timeresolved analysis (TRA) using a fast peak-hopping sequence. Each spot analysis consisted of $c .60 \mathrm{~s}$ background acquisition (gas blank) followed by c. $60 \mathrm{~s}$ sample; ablation used a $\sim 30 \mu$ m diameter laser beam. Twenty-seven isotopes were analysed in this study, including ${ }^{43} \mathrm{Ca}$ as the internal standard (IS) using the concentrations obtained by EPMA. Both ${ }^{86} \mathrm{Sr}$ (isotopic abundance $\sim 9.86 \%$ ) and ${ }^{88} \mathrm{Sr}$ (isotopic abundance $\sim 82.58 \%$ ) were analysed to assess the effect of linear calibration for variable element contents.
Samples were measured in short runs bracketed by analyses of the external standard (ES) NIST SRM 610, with reference values taken from Norman et al. (1996). After each analysis, data reduction was carried out using Version 4.0 of the 'real-time on-line' GLITTER (C) software (Griffin et al., 2008), which allows the user to select a data range free of effects produced by ablating inclusions. As there is no matrix-matched and homogeneous apatite-like standard available, NIST SRM 610, NIST SRM 614 and USGS international standards, including BCR-2(G), TB-1 (a basaltic glass) and GSE-1 (a doped rock-glass), were analysed as secondary standards during the analytical runs to test the accuracy and precision of the LA-ICP-MS method. The REE concentrations of apatites are generally between those of NIST SRM 610 and BCR-2(G).

One hundred analyses of NIST SRM 610 show that the minimum limit of detection (LOD) of this method for most trace elements in igneous rocks is around the ppm level, commonly not more than $10 \mathrm{ppm}$. For REE, minimum LODs are substantially below the ppm level and mostly not more than $2 \mathrm{ppm}$. Comparison of our results with those from the literature or the compiled values for standard materials show that they are mutually consistent with an accuracy better than 5\% relative (Electronic Appendix Table 1, available for downloading at http:// www.petrology.oxfordjournals.org). This agreement implies that matrix effects are not significant during our measurements when the doped synthetic glass is used as the external standard for natural sample measurements. Accordingly, this method can be applied to the trace element analysis of apatite. For further comparison, JC4, an apatite EPMA reference material, was analysed as an unknown sample and these results are listed in Electronic Appendix Table 1.

Precision for elements with mass $>80$ is inversely correlated with element abundance, from $4-5 \%$ for $\sim 450 \mathrm{ppm}$ (NIST SRM 610 ) to $7-14 \%$ for $\sim 0.8 \mathrm{ppm}$ (NIST SRM 614; Electronic Appendix Table 1). Regardless of concentrations or matrix, the precision for $\mathrm{Zn}, \mathrm{Rb}, \mathrm{Sn}, \mathrm{Sb}, \mathrm{Cs}$, and $\mathrm{Pb}(\sim 10-20 \%)$ is significantly poorer than for the other analytes in any sample. This lower precision may be due to the fractionation of these elements relative to the IS (see Günther et al., 1999), or to heterogeneity in the reference glasses on the scale of the LA-ICP-MS spatial resolution (see Eggins \& Shelley, 2002).

\section{MINOR ELEMENTS:ANALYTIGAL RESULTS AND DISGUSSION}

In the following discussion, the aluminum saturation index [ASI, calculated as molecular $\mathrm{Al}_{2} \mathrm{O}_{3} /\left(\mathrm{Na}_{2} \mathrm{O}+\mathrm{K}_{2} \mathrm{O}+\right.$ $\mathrm{CaO})]$ of the host-rocks is used to illustrate the range of elemental variations in the Transhimalayan apatites. For the studied samples, ASI increases in general with the 


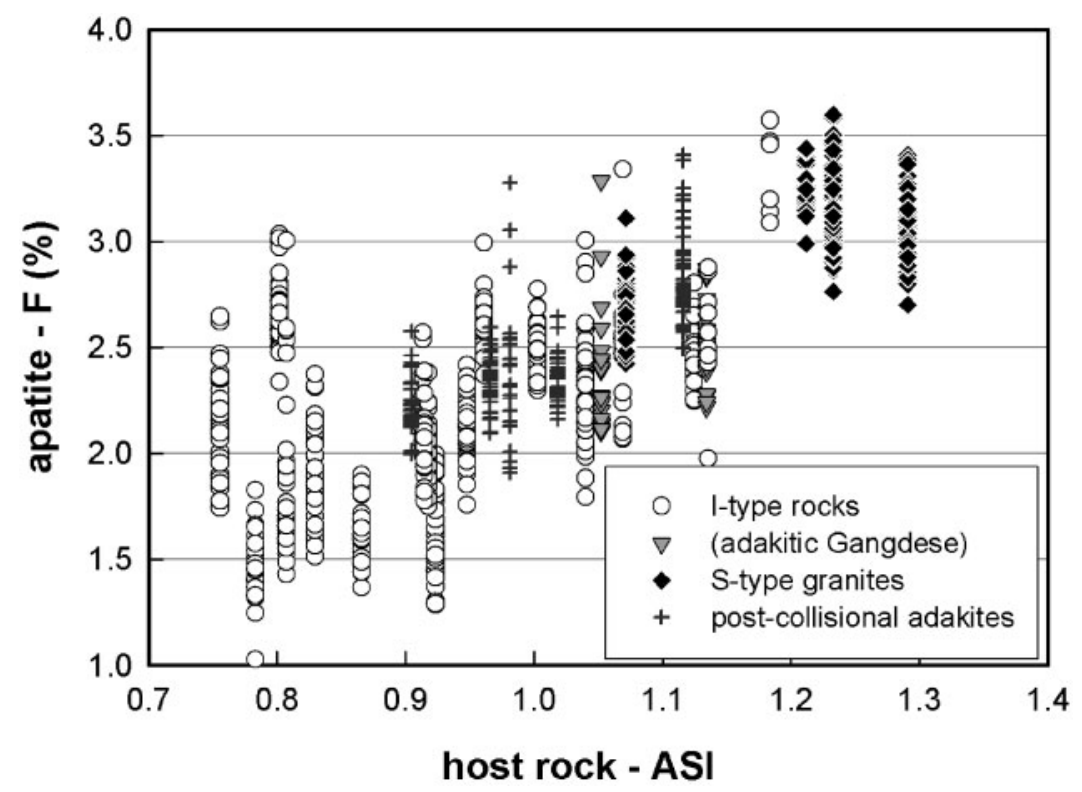

Fig. 2. F contents of apatites from different rock types: apatite F vs host-rock ASI.

silica content of the host-rock, regardless of rock type (Table 1). If host-rock silica contents were used instead, it would not make any difference to our discussion or conclusions, although the scatter of apatite compositions relative to this index of magma evolution would become greater (see Fig. 2 and Electronic Appendix Fig. 1).

In the subsequent discussion, plutons with ASI $\geq 0.9(\geq$ $\sim 57$ wt $\% \mathrm{SiO}_{2}$ ), except adakites, are termed granites and those with ASI $<0 \cdot 9$, generally equivalent to $<57 \mathrm{wt} \%$ $\mathrm{SiO}_{2}$, are termed 'mafic rocks.' According to this classification, the characteristics of minor element distributions in apatites (Electronic Appendix Table 2) from different types of Transhimalayan igneous intrusions are summarized below.

\section{Fluorine and chlorine}

Most of the apatites are fluorapatite, typical of igneous apatite, with $\mathrm{F}$ contents $>1 \mathrm{wt} \%$, and $\mathrm{F} / \mathrm{Cl}>1$ (Electronic Appendix Table 2). The abundance of $\mathrm{F}$ increases, and that of $\mathrm{Cl}$ decreases, with increasing ASI (Fig. 2). However, apatites in some S-type granites (e.g. T1048 and T138) have $\mathrm{Cl}$ contents below the detection limits of EPMA; these analyses may have much higher $\mathrm{F} / \mathrm{Cl}$ ratios than those shown calculated from the actual analyses (see Electronic Appendix Table 2). Accordingly, although F and $\mathrm{Cl}$ abundance and/or the $\mathrm{F} / \mathrm{Cl}$ ratios of apatite have the potential to monitor magma evolution, the $\mathrm{F}$ content is recommended as the better indicator.

The range of $\mathrm{F}$ concentrations analysed in one apatite grain is up to $0.33 \%$, and the range within one rock sample generally is from 0.5 to $1.5 \%$. For a rock sample with a specific ASI value, the $\mathrm{F}$ variation in its apatites is up to $\sim 1.8 \%$.

\section{Manganese and iron}

Mn variations in a single apatite separate can be up to $0 \cdot 1$ wt $\%$. Whole-rock ASI values exert a control on the Mn content of apatite in all types of Transhimalayan intrusion (Fig. 3), independent of the host-rock Mn abundance (Table 1). In metaluminous (ASI $<1$ ) host rocks such as most adakites, (I-type) mafic rocks and some I-type granites, apatite consistently has $<0 \cdot 2 \% \mathrm{MnO}$. In peraluminous rocks with $\mathrm{ASI} \geq 1 \cdot 1$, both the $\mathrm{MnO}$ concentrations of apatite and the proportions of apatite grains with $>0.2 \% \mathrm{MnO}$ rise with the host-rock ASI values. In rocks with $1 \leq \mathrm{ASI}<1 \cdot 1$, the $\mathrm{MnO}$ abundances of apatite are transitional. Therefore, the Mn content of apatite can be used as an indicator of the ASI of magmatic rocks.

Iron concentrations in apatite from all Transhimalayan plutonic rocks are mostly lower than $0 \cdot 2 \% \mathrm{FeO}$, except in some highly evolved S-type granites (e.g. T170A: up to 14\%; Electronic Appendix Table 2). The host-rock total iron contents (Table 1) appear to have little effect on the $\mathrm{FeO}$ contents in apatite.

\section{Sulfur}

Sulfur (expressed as $\mathrm{SO}_{3} \mathrm{wt} \%$ ) in apatites from peraluminous rocks falls with increasing ASI of the host rocks, to the extent that more than half of the data are below the EPMA detection limit (0.01-0.001 wt \% $\mathrm{SO}_{3}$; Electronic Appendix Table 2). In metaluminous Transhimalayan plutons, the S contents of apatite cover a wide range (Fig. 4) and are irregularly correlated with variation in host-rock ASI.

As for $\mathrm{Mn}$ and $\mathrm{Fe}, \mathrm{S}$ abundances in apatite may be related to the redox condition of the host magma. In an 
Table 2: Summary of the geochemical characteristics of apatite in different types and aluminosities of Transhimalayan granitoids

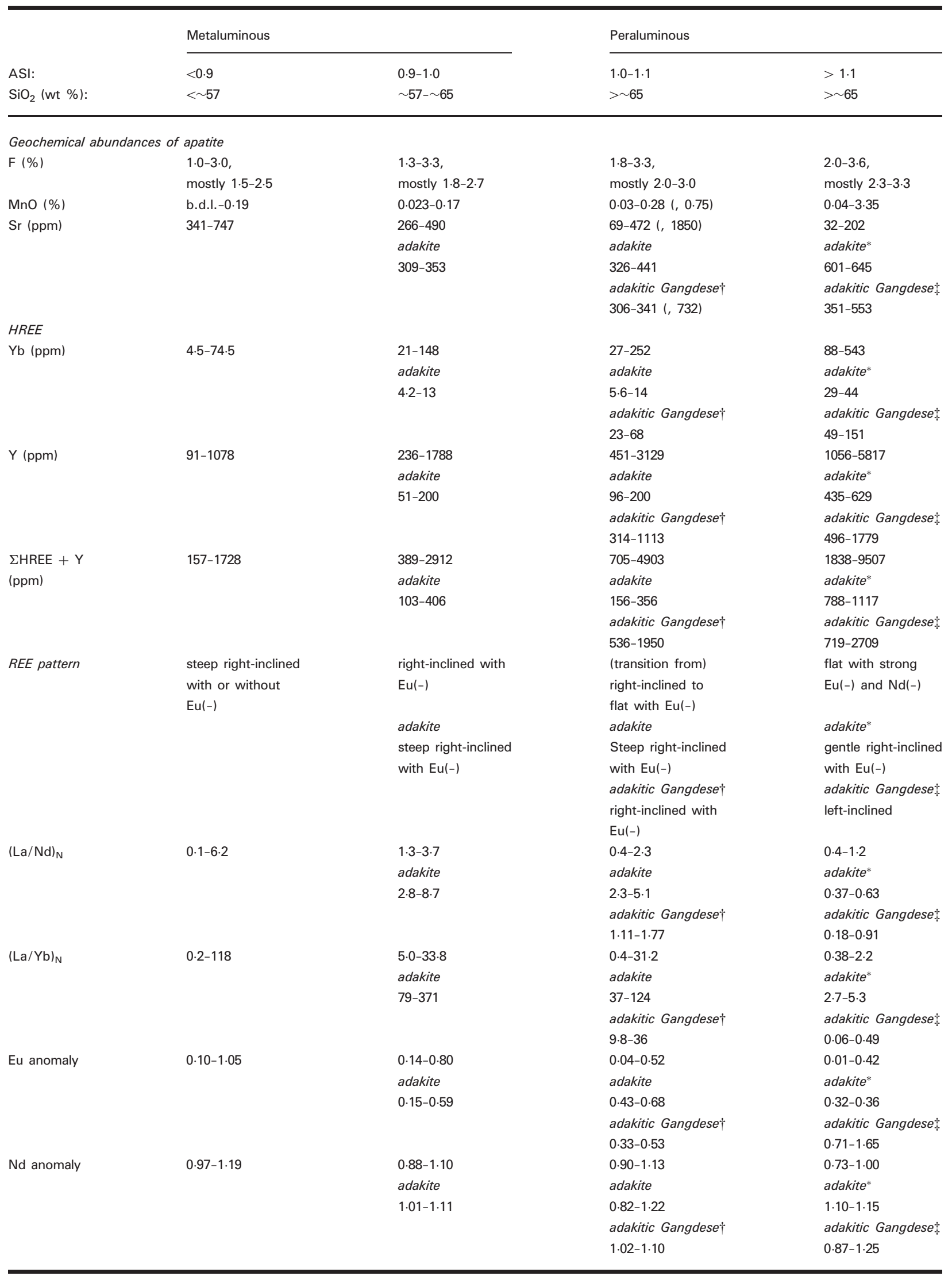

Eu(-), negative Eu anomaly in REE pattern; Nd(-), negative Nd anomaly in REE pattern. b.d.I., below detection limit.

*Data from sample T016.

†Data from sample T027.

†Data from sample T024. 


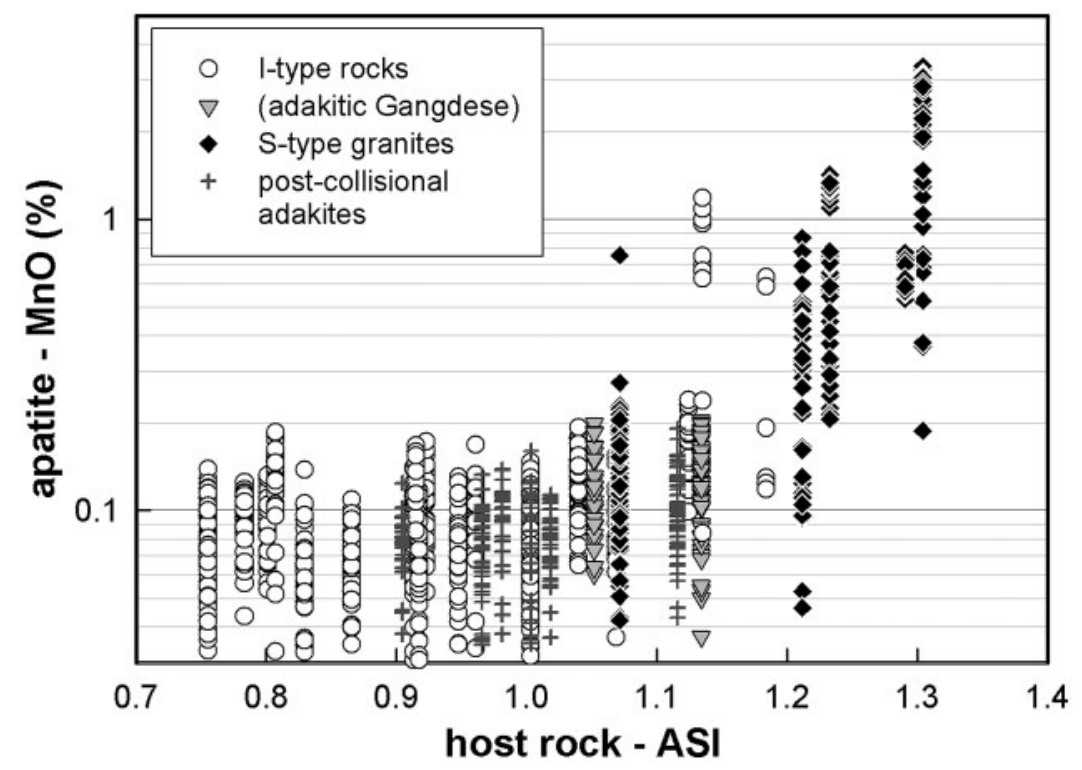

Fig. 3. $\mathrm{MnO}$ contents of apatites from different rock types: apatite $\mathrm{MnO}$ vs host-rock ASI.

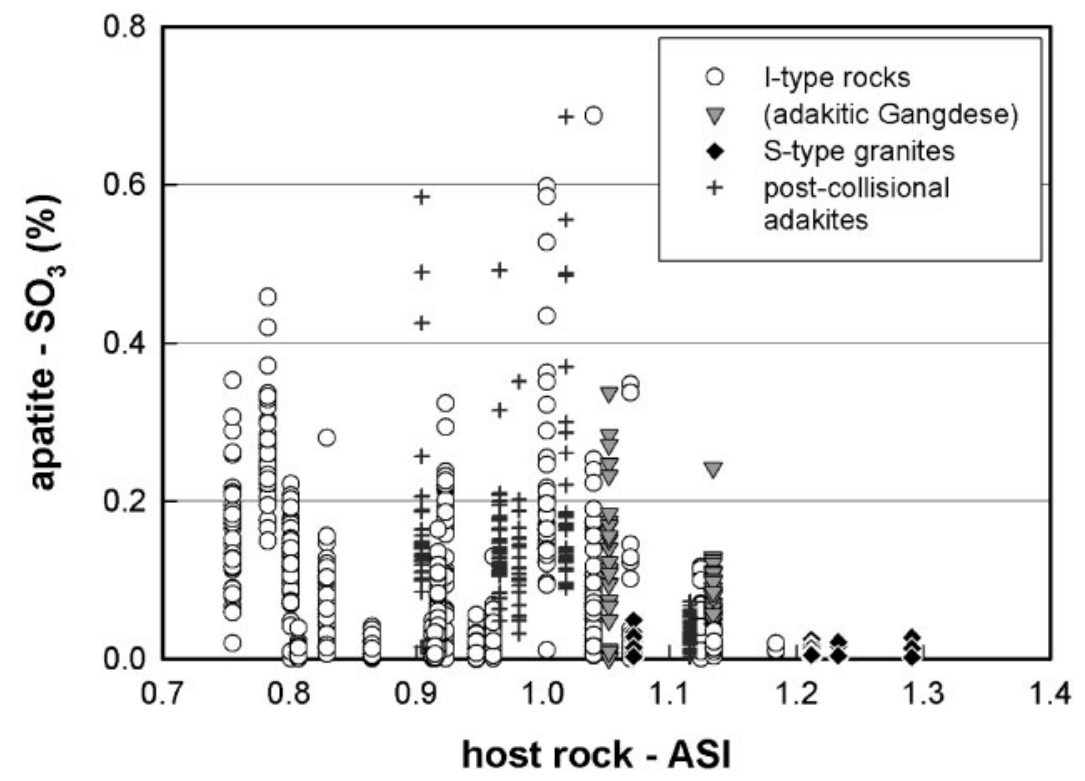

Fig. 4. $\mathrm{SO}_{3}$ contents of apatites vs host-rock ASI for different rock types.

oxidizing magma, more $\mathrm{S}$ occurs as $\mathrm{SO}_{4}{ }^{2-}$ and thus can easily replace $\mathrm{PO}_{4}{ }^{3-}$ in apatite (see Sha \& Chappell, 1999). However, no correlation between any two of $\mathrm{SO}_{3}$, $\mathrm{MnO}$ and $\mathrm{FeO}$ is observed in the Transhimalayan apatites.

\section{Sodium}

Apatites from different Transhimalayan rocks generally have similar Na contents (mostly $\mathrm{Na}_{2} \mathrm{O}<0.2 \%$ ); however, $\mathrm{Na}$ increases slightly with magma fractionation in the (peraluminous) S-type granites. The variations in the sodium contents of apatite are not as clear and systematic as those reported from the granites of the Lachlan Fold Belt by Sha \& Chappell (1999).

\section{TRACE ELEMENTS: RESULTS}

\section{AND DISGUSSION}

\section{Strontium}

Sr concentrations in apatite grains separated from a single rock are variable, but mainly confined to the range of 0.25 $\leq \mathrm{Sr}_{\text {apatite }} / \mathrm{Sr}_{\text {host-rock }} \leq 1$ (Fig. 5a; Electronic Appendix 

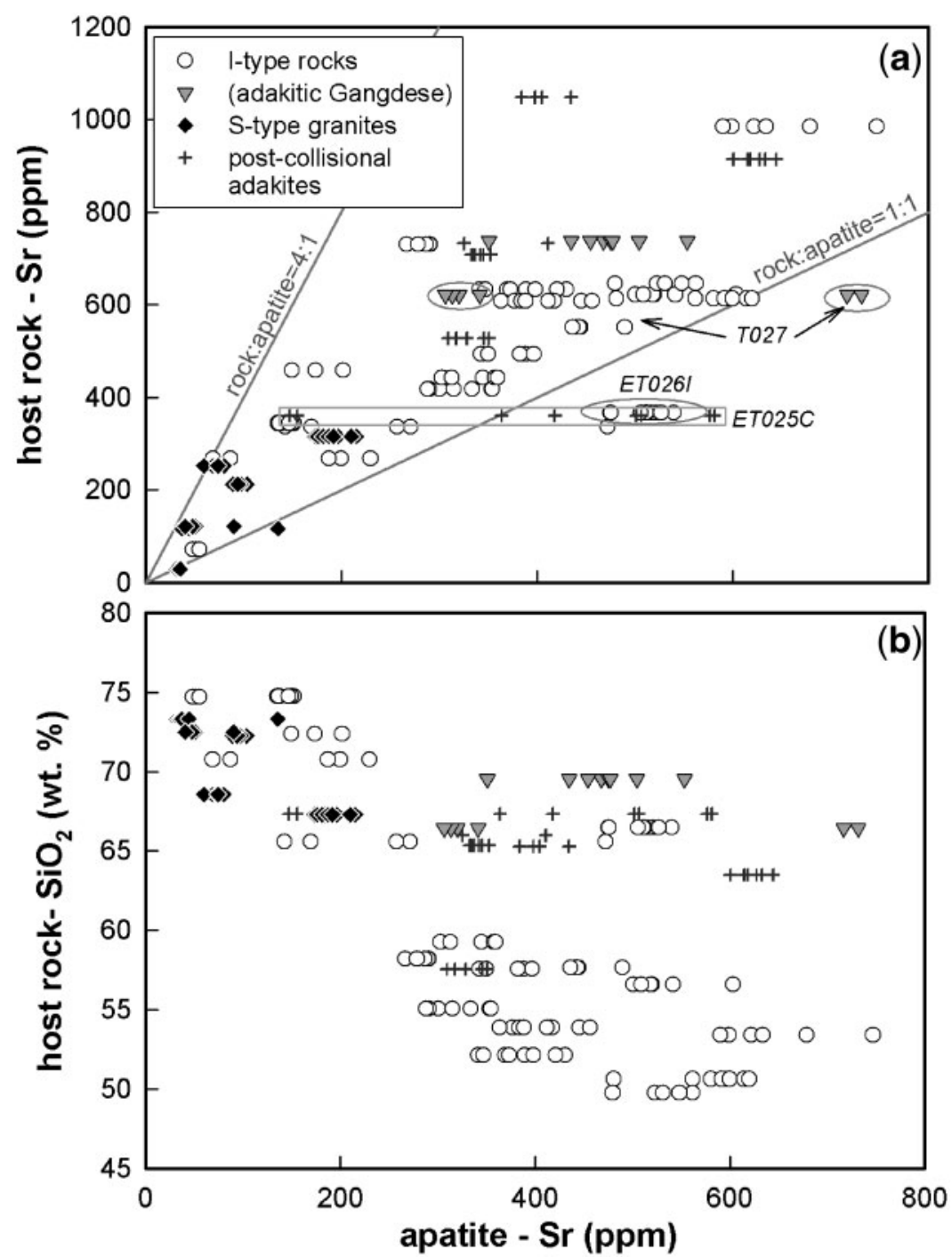

Fig. 5. Variation of $\mathrm{Sr}$ content of apatite as a function of (a) $\mathrm{Sr}$ and (b) $\mathrm{SiO}_{2}$ content of the host-rocks.

Table 3). The Sr content of apatites from S-type granites have a restricted range, with variations less than $100 \mathrm{ppm}$ (mostly $<50 \mathrm{ppm})$. In apatites from I-type intrusions and adakites the range of $\mathrm{Sr}$ contents may be up to $330 \mathrm{ppm}$ (mostly 20-150 ppm). However, a few analyses extend to more than $400 \mathrm{ppm}$ (T027 and ET025C) and these Sr values are higher than those of the host-rocks.

The Sr contents of apatites from the Transhimalayan plutonic rocks are generally correlated with the $\mathrm{Sr}$ in the host-rock (Fig. 5a), as observed in other studies (e.g. Sha \& Chappell, 1999). For example, adakites and (I-type) Gangdese adakitic rocks commonly have higher Sr concentrations than other Transhimalayan rocks with the same $\mathrm{SiO}_{2}$ contents or ASI, a feature ascribed to the rarity of residual plagioclase in their sources (Fig. 5b; Chung et al., 2003). The Sr contents of apatites from these rocks are comparable with those from (I-type) mafic rocks; the underplated equivalents of these mafic rocks have been suggested as a likely source of adakitic magmas (Chu, 2006; Wen et al., 2008a). However, apatites from I-type granite (ET026I) have high $\mathrm{Sr}$ abundances similar to those in adakitic rocks (Fig. 5b), and have much higher $\mathrm{Sr}$ contents than their host-rocks. All of these examples are discussed in more detail below.

Because Sr abundances, major element concentrations and the levels of some other trace elements in igneous rocks of a single suite vary with the degree of fractionation (e.g. whole-rock $\mathrm{SiO}_{2}$ ) and $\mathrm{ASI}$, the $\mathrm{Sr}$ contents of apatites might be used as a monitor of whole-rock composition. Belousova et al. (2001) showed that the Sr contents of apatites from granites of four different (super-) suites in the Mt. Isa Inlier, Australia, exhibit a systematic variation 


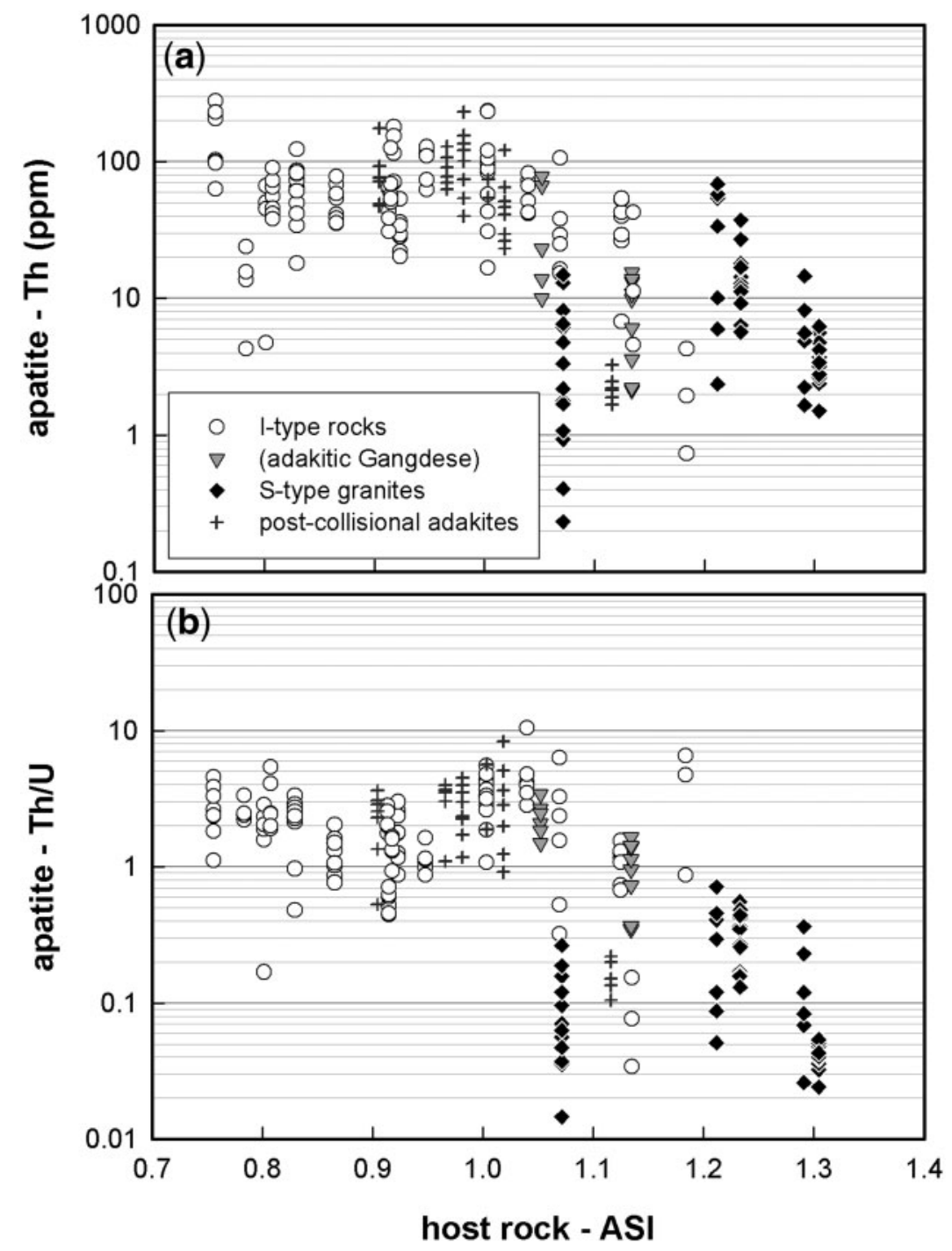

Fig. 6. Variation of (a) Th, and (b) Th/U in apatites vs host-rock ASI.

with whole-rock $\mathrm{SiO}_{2}, \mathrm{Al}_{2} \mathrm{O}_{3}, \mathrm{FeO}, \mathrm{K}_{2} \mathrm{O}$ and $\mathrm{Rb} / \mathrm{Sr}$. However, in the I-type Gangdese batholith it is difficult to see such correlations; for example, between the Sr contents of apatite and the $\mathrm{K}_{2} \mathrm{O}$ content of their host-rocks. This probably is because in the Gangdese belt, the $\mathrm{K}_{2} \mathrm{O}$ contents of the intrusive rocks show no correlation with their $\mathrm{Sr}$ and $\mathrm{SiO}_{2}$ contents (Table 1). Thus the potential of $\mathrm{Sr}$ in apatite to predict whole-rock composition essentially depends on how well whole-rock $\mathrm{SiO}_{2}$ correlates with other element abundances. This application of apatite $\mathrm{Sr}$ contents is feasible in principle, but must be independently defined for each suite.

\section{Thorium and uranium}

The behavior of Th and $\mathrm{U}$ in apatite is independent of the composition and type of the host-rocks (Fig. 6). In the metaluminous granites and adakites, the Th contents of apatites vary mainly from 20 to $200 \mathrm{ppm}$, similar to the range in the (metaluminous) mafic rocks. In the peraluminous rocks, apatite can have lower Th concentrations, commonly 2-50 ppm. The depletion of Th in these apatites can be attributed to the crystallization of monazite, (Ce, La, Th, Nd, Y) $\mathrm{PO}_{4}$, before and/or concurrently with apatite, as monazite is one of the main accessory phases in peraluminous magmas but not in metaluminous ones. There is no distinguishable difference in $\mathrm{U}$ content among apatites in adakites, I-type rocks and S-type granites with different aluminosities; most values are between 10 and $100 \mathrm{ppm}$. The small range of $\mathrm{Th} / \mathrm{U}(\sim 0 \cdot 5-6)$ of apatites in metaluminous granitoids reflects these consistent $\mathrm{Th}$ and U contents (Fig. 6b). In peraluminous granites, apatite $\mathrm{Th} / \mathrm{U}$ ratios span a wider range from $\sim 0.01$ to $\sim 20$ because 
of the variable Th contents. These observations for the granites are inconsistent with those made in the Lachlan Fold Belt (Sha \& Chappell, 1999).

\section{Rare earth elements (REE) REE concentrations}

A whole-rock ASI between 1.0 and 1.1 also marks a boundary in the behavior of the REE in apatite (Fig. 7). Regardless of rock type, apatites from metaluminous Transhimalayan rocks have lower contents of the HREE (Gd to Lu plus Y: 100-2000 ppm) than apatites from peraluminous granites (400-10000 ppm), although both groups of apatite have similar light REE (LREE) contents (La to Eu: mostly 1000-10 000 ppm).

The around 10-times enrichment of HREE in apatites from peraluminous rocks may reflect (1) relatively fewer HREE-rich accessory minerals competing for the HREE in the evolved melts when apatite crystallized, or (2) a pronounced increase in partition coefficients $(D)$ for the HREE relative to LREE. The measured REE partition coefficients of apatite in granites are highly variable (Electronic Appendix Table 4) and possibility (2) cannot be properly evaluated before there is a better understanding of these HREE values. With regard to the first possibility, xenotime, zircon and amphibole are known to concentrate the HREE (Bea, 1996). Xenotime is not a ubiquitous phase in Transhimalayan peraluminous magmas. Zircon can be found in both peraluminous and metaluminous Transhimalayan rocks. However, zircons in peraluminous S-type granites are mainly inherited and the lesser competition from zircon could be the reason for the high HREE in apatite. In the I-type peraluminous granites, apatite can capture more of the HREE budget because of the lesser crystallization of amphibole, which is common in metaluminous magmas but not in peraluminous ones.

In apatite from Transhimalayan intrusions, the differences in the abundances of single REE show similar trends to the total contents of LREE and HREE (including Y). In this study, apatite in general contains 1000-20000 ppm REE (including Y). The total LREE abundances of Transhimalayan apatites are essentially constant over a range of whole-rock aluminosity. The somewhat higher HREE contents of apatites in peraluminous granites lead to somewhat higher total REE contents.

\section{REE patterns}

Transhimalayan apatites show significant variations in chondrite-normalized REE patterns (Figs 8-11) between different rock types. In a single apatite, the within-grain variation in absolute REE abundances can be large (e.g. La: up to 1000 ppm; Electronic Appendix Table 3), but there is no significant difference in the shape of the REE patterns.
Apatites from the metaluminous rocks, including adakites, are characterized by LREE-enriched patterns, with little or no Eu depletion (Figs $8 \mathrm{a}^{-} \mathrm{c}$ and $9 \mathrm{a}-\mathrm{k}$ ). Their enrichment in LREE relative to HREE and Eu in general falls with increasing ASI, accompanying the fractionation of the host magma (Figs 12 and 13a). In the I-type Gangdese magmatic suite, the apatites with the most markedly LREE-enriched patterns and the least Eu depletion are all from the least fractionated Gangdese mafic rocks (Fig. 9a, c-e), except for one special case, granite ET026I (Fig. 9l). However, the most pronounced enrichment of LREE relative to HREE can be observed in apatites from adakites (ASI $>0.9$ ), although these commonly have a significant negative $\mathrm{Eu}$ anomaly $($ Fig. $8 \mathrm{a}-\mathrm{c}$ ); the relative LREE enrichments reflect the low HREE contents of the magma from which the apatites crystallized. The compositions of the source rocks of the magmas are thus an important control on the apatite REE patterns.

In contrast to apatites in metaluminous rocks, the REE patterns of those in the peraluminous granites, especially those with ASI $>1 \cdot 1$ (Figs 8f, 9o-q, 10b and 11b-f), are essentially flat, or upwardly convex in linear-scale plots, and show Eu and $\mathrm{Nd}$ depletion; they are similar to the patterns of apatite in granites from the Lachlan Fold Belt and south China (Sha \& Chappell, 1999; Hsieh et al., 2008). The relatively low LREE abundances of these apatites probably reflect the crystallization of accessory phases, including allanite (Electronic Appendix Table 5a) and particularly monazite (Electronic Appendix Table 5b).

Apatite in the only peraluminous (post-collisional) adakite (T016) is mildly LREE-depleted (Fig. 8f). In fact, these patterns show lower LREE and higher HREE than those of apatite in metaluminous (post-collisional) adakites, which is consistent with the difference between apatites in metaluminous and peraluminous 'common' granitoids. Variations of apatite HREE in adakites and adakitic Gangdese rocks essentially follow the trend defined by I- and S-type plutonic rocks, but their abundances are much lower owing to the HREE depletion in the magmas (Fig. 7). Such LREE-enriched patterns represent 'common' flat REE patterns modified by the HREEdepleted magma composition.

Apatites in peraluminous I-type Gangdese suite rocks and adakites, both with ASI of $1-1 \cdot 1$, show variable REE patterns (Figs 8d and e, 9m and n, 10a and 11a), which can be LREE-enriched, flat and/or transitional, sometimes with moderate $\mathrm{Nd}$ and $\mathrm{Eu}$ depletion, like those of T148A (Fig. 9n) and ST146A (Fig. 9o). However, those in the S-type granites show coherent flat patterns with pronounced negative $\mathrm{Nd}$ and $\mathrm{Eu}$ anomalies (Fig. 1la).

LREE-depleted patterns are also observed in Transhimalayan apatites. Some apatites in the titanitebearing I-type mafic rock ST147A show $\mathrm{La}-\mathrm{Nd}$ depletion 

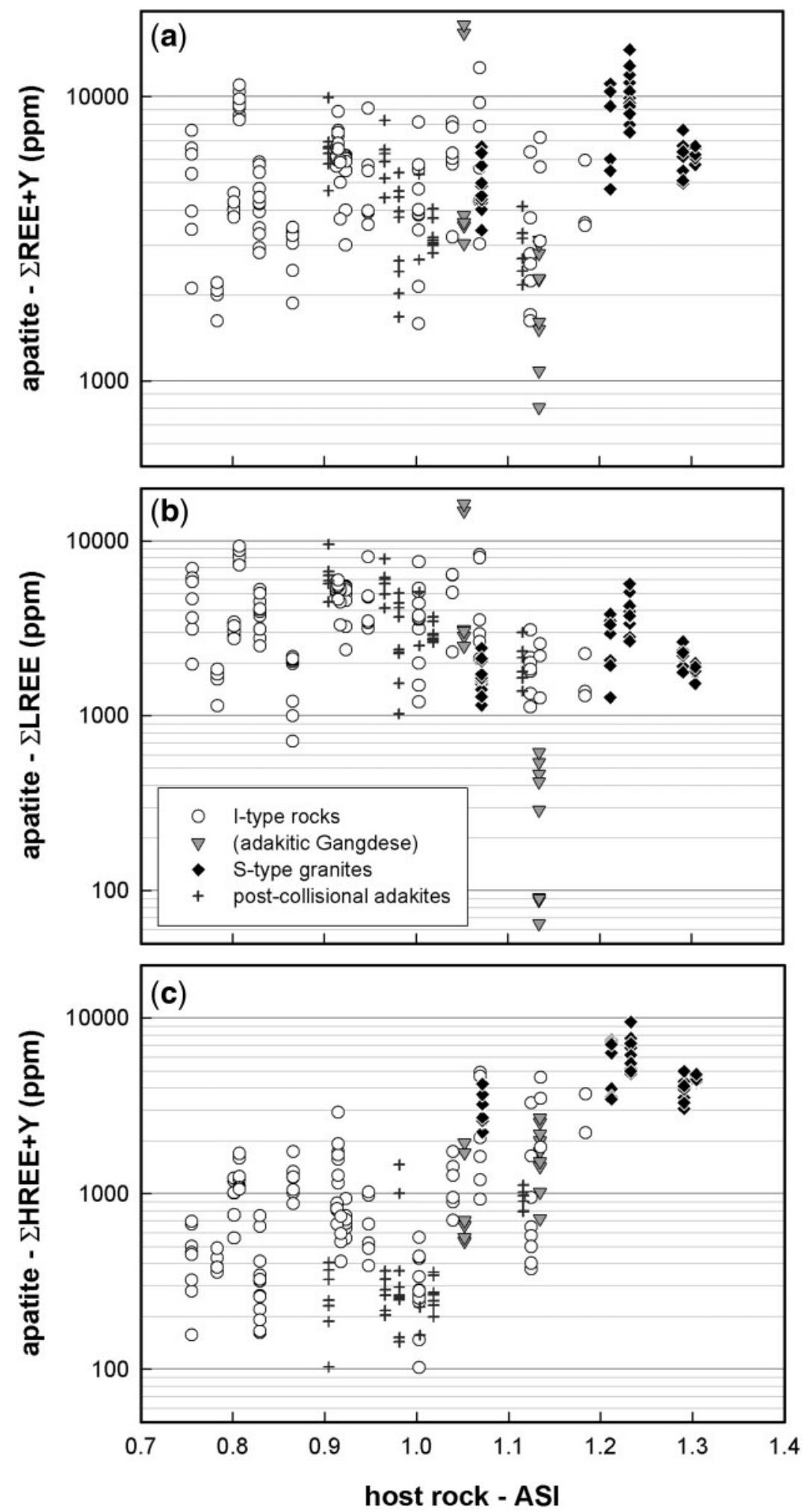

Fig. 7. Variation of (a) total REE and Y, (b) total LREE and (c) total HREE and Y contents in apatites vs host-rock ASI. 

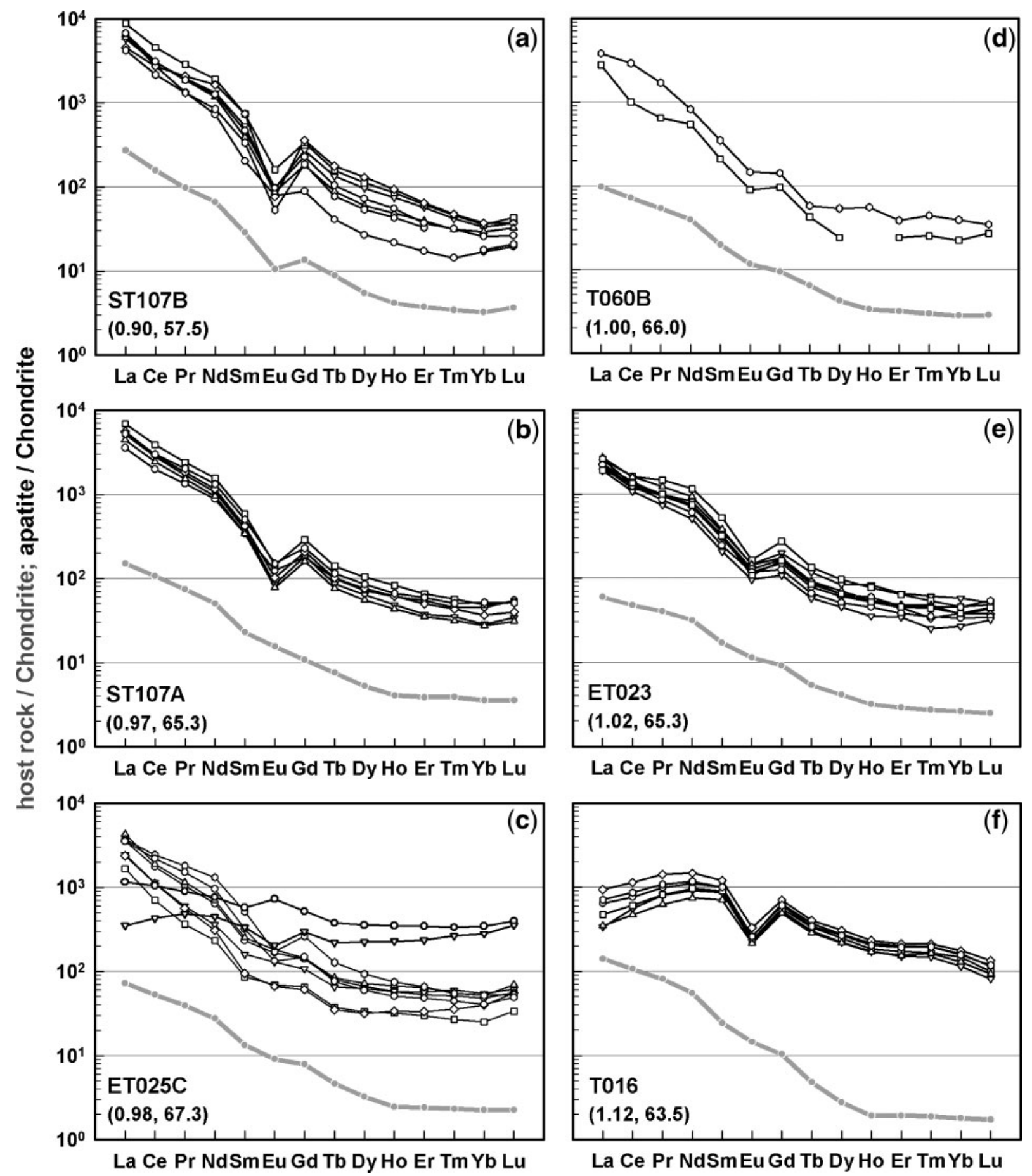

Fig. 8. Chondrite-normalized REE patterns of apatites (black lines with open symbols) and their host-rocks, Transhimalayan adakites (light grey lines with filled symbols); ASI and silica content of the bulk-rock are given in parentheses for reference. Chondrite REE values from Taylor \& McLennan (1985).

patterns with a Eu negative anomaly (Fig. 9f). The concentration of La can be down by a factor of 10. The three apatites with the most depleted LREE patterns have slightly lower Sr contents in comparison with the other apatites (around 15-90 ppm difference). The crystallization of titanite can cause these compositional variations, with a strong depletion in LREE and mild depletion in $\mathrm{Sr}$ in coexisting apatite. A similar pattern is also observed 


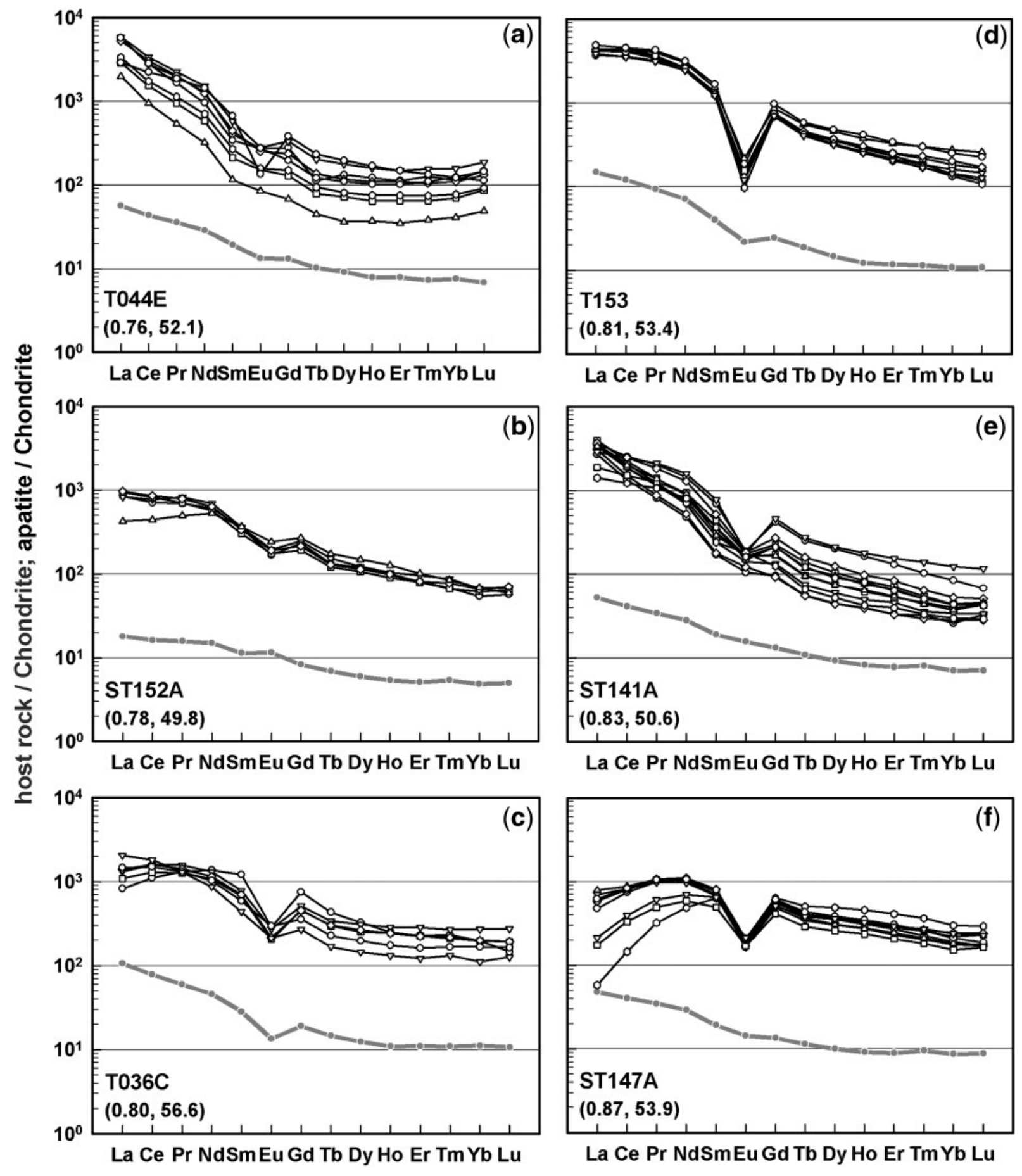

Fig. 9. Chondrite-normalized REE patterns of apatites (black lines with open symbols) and their host-rocks, Transhimalayan I-type Gangdese rocks (light grey lines with filled symbols); ASI and silica content of the bulk-rock are given in parentheses for reference.

in apatites in another titanite-bearing I-type mafic rock, ET021E (Fig. 9i).

LREE-depleted patterns, with depletion extending as far as $\mathrm{Gd}$, are observed in apatites from strongly fractionated granites (e.g. T024; Fig. 10b). Such patterns have been reported from apatite in Norwegian granite pegmatites and other granitoids and may be more common in highly evolved granites, including pegmatites 

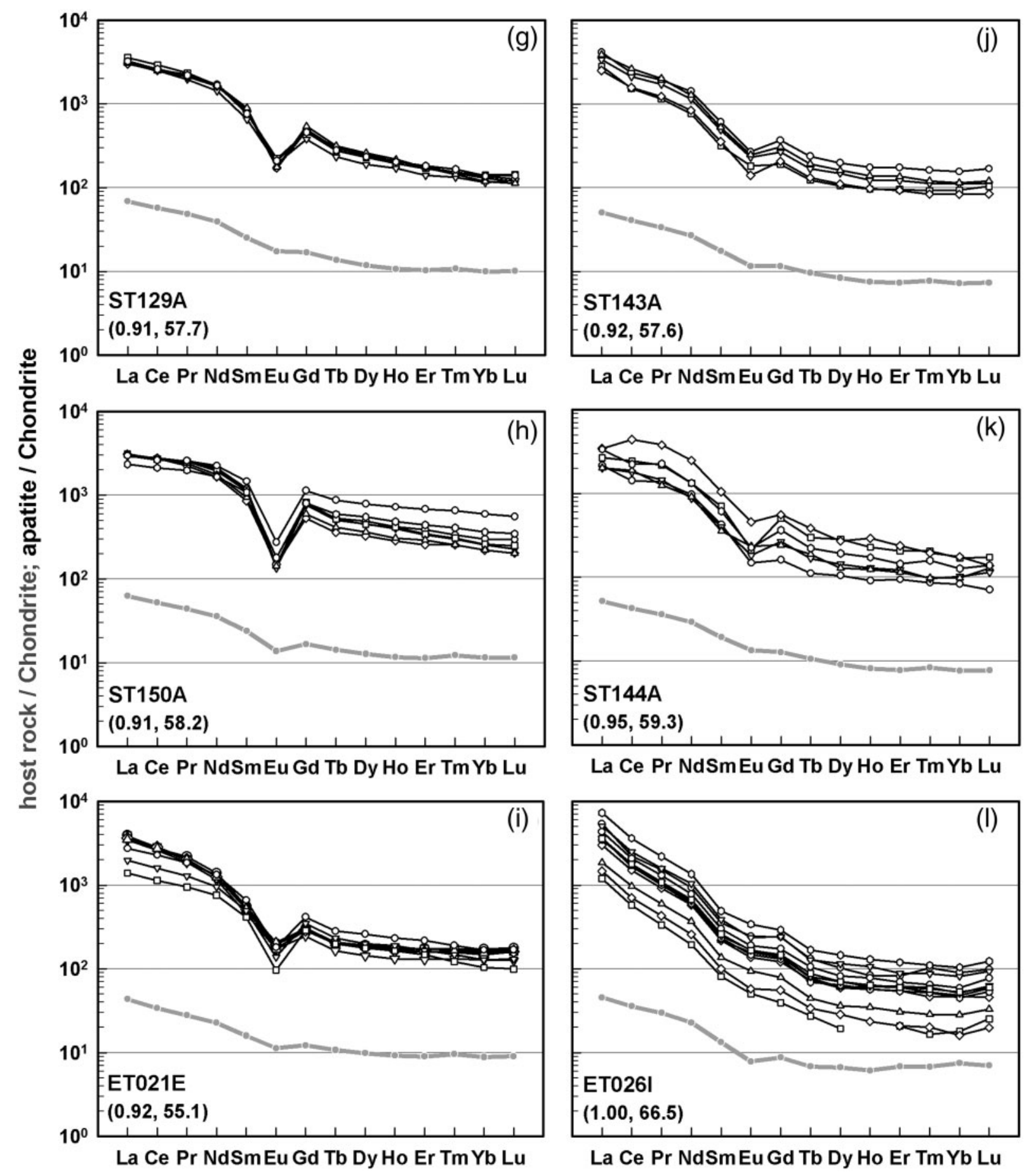

La Ce Pr NdSmEu Gd Tb Dy Ho Er Tm Yb Lu

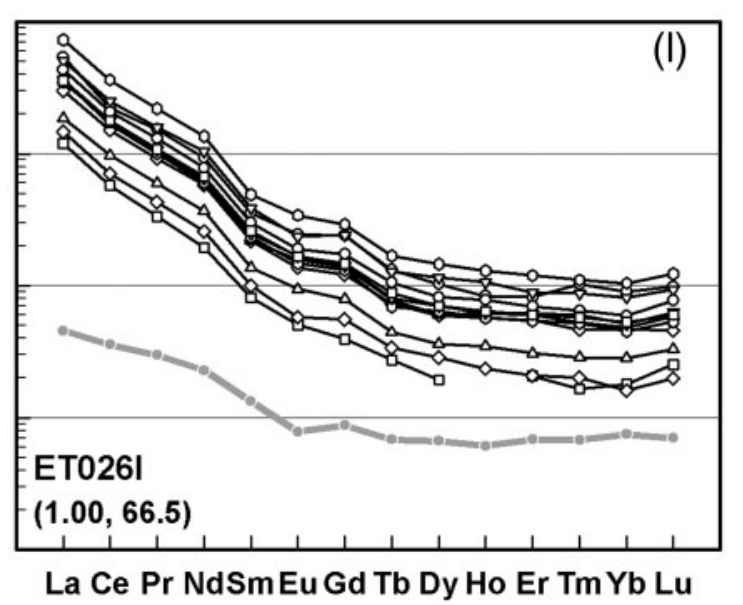

Fig. 9. Continued

(Belousova et al., 2002). The much stronger depletion of these apatites in LREE results from competition with the abundant LREE-enriched minerals in T024, including allanite, epidote, and feldspar (mainly K-feldspar) (Wen et al., 2008a). Unfortunately, in this study, we have not observed any examples of transitions between flat and
LREE-depleted patterns. Whether there are evolutionary relationships between them remains uncertain.

A negative $\mathrm{Nd}$ anomaly in REE patterns is typical of apatites with flat REE patterns from granites of the Lachlan Fold Belt (Sha \& Chappell, 1999) and the Nanling Mountains, south China (Hsieh et al., 2008), and 

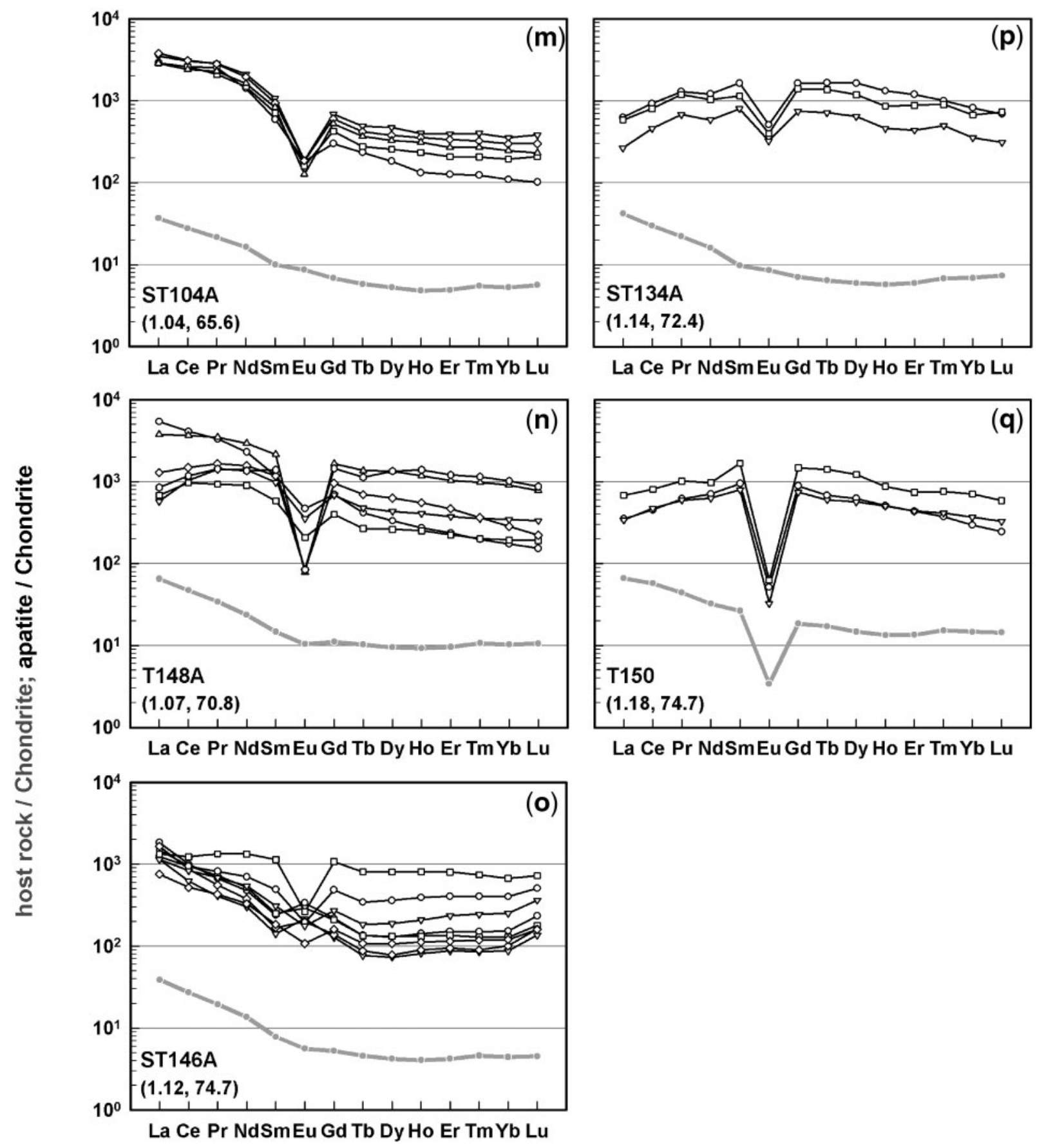

La Ce Pr NdSmEu Gd Tb Dy Ho Er Tm Yb Lu

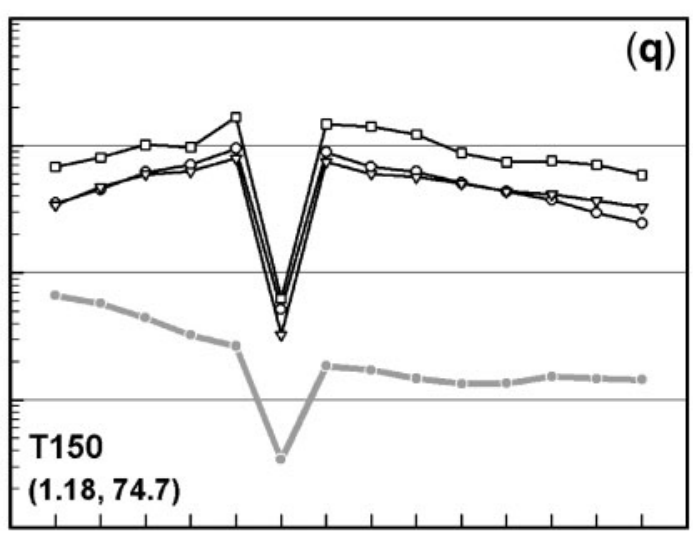

La Ce Pr NdSmEu Gd Tb Dy Ho Er Tm Yb Lu

Fig. 9. Continued.

is also seen in apatites from the peraluminous Transhimalayan granites. Apatites from T148A and ST146A show a transition between LREE-enriched and flat REE patterns; Nd depletion is not present in the flat patterns. The Nd anomaly is particularly conspicuous in apatites crystallized from S-type and evolved I-type magmas (Figs 9p and q, and 11).
Mainly following the crystallization of feldspar and other minerals, in I-type and S-type intrusions the Eu anomaly in apatite in general becomes more negative as the aluminosity of the host-rock increases (Fig. 13a) and more specifically, as its LREE enrichment decreases (Fig. 13b). However, there are two main exceptions, T024 and ST146. In the former, because apatite has a 


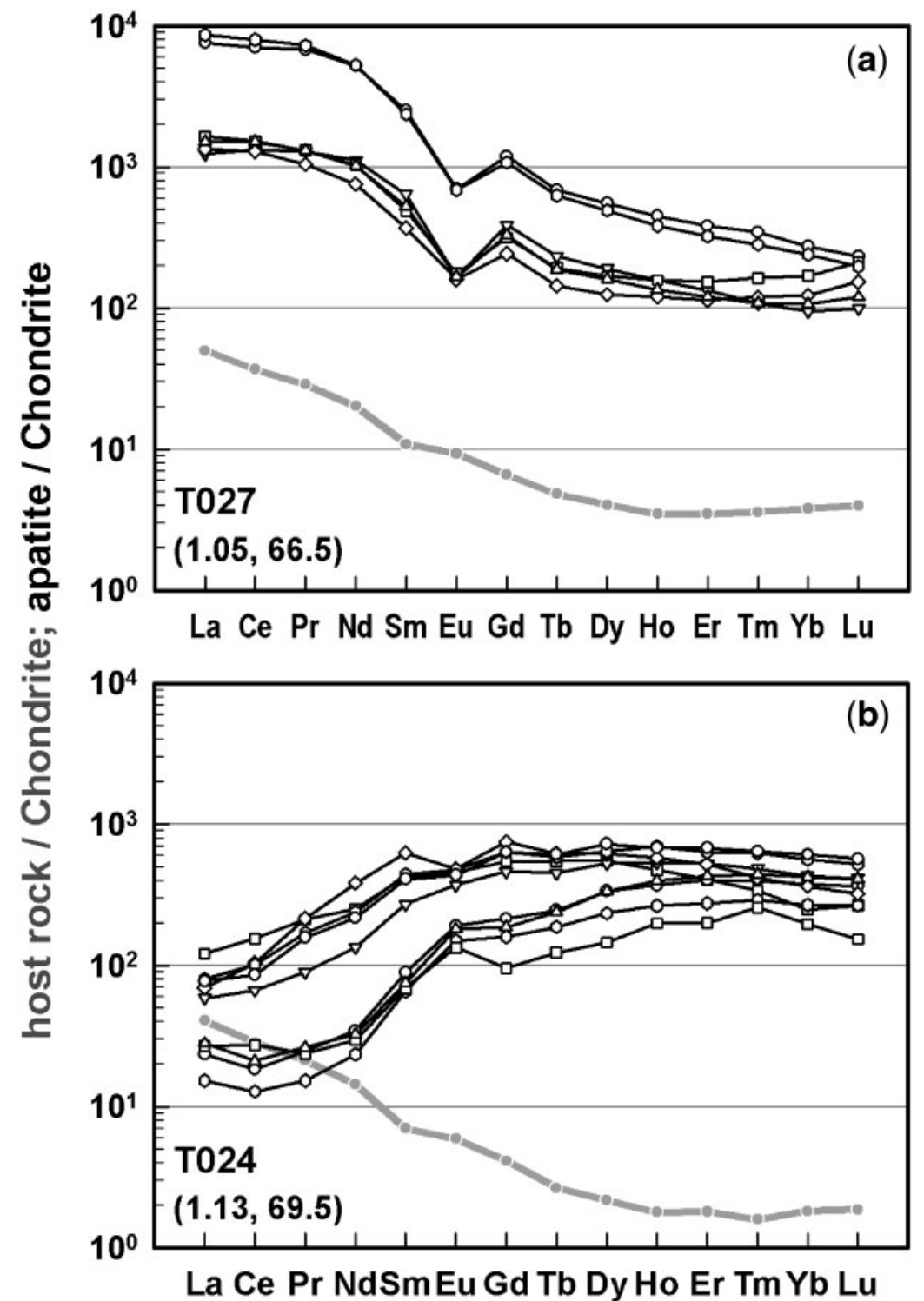

Fig. 10. Chondrite-normalized REE patterns of apatites (black lines with open symbols) and their host-rocks, I-type adakitic Gangdese rocks (light grey lines with filled symbols); ASI and silica content of the bulk-rock are given in parentheses for reference.

comparable absolute Eu abundance, its strong LREE depletion reduces the apparent negative Eu 'anomaly' (Fig. 10b). The positive Eu anomaly of apatite in ST146 provides specific petrogenetic information (discussed below). Moreover, the common relationships between Eu depletion and LREE enrichment and host-rock aluminosity are not observed in the adakites (Fig. 13).

\section{I S C US S I O N}

\section{Nd depletion in apatite of peraluminous magmas}

Sha \& Chappell (1999) showed that Nd depletion in apatite from peraluminous intrusions does not reflect the bulk-rock composition, and argued that it reflects the crystallization of monazite. Monazite is a common accessory mineral in peraluminous, but not metaluminous magmas and its REE partition coefficients peak at Nd (Yurimoto et al., 1990; Electronic Appendix Table 5b). However, this interpretation may be inadequate.

As in the granites of the Lachlan Fold Belt (Sha \& Chappell, 1999), there seems to be little $\mathrm{Nd}$ depletion in the host-rock REE patterns of the peraluminous Transhimalayan rocks (Figs 8-11), although their apatites all have negative $\mathrm{Nd}$ anomalies. However, because of apatite's high partition coefficient for REE, it has the ability to 'amplify' a subtle negative Nd anomaly present in its host-rock and make it visible when plotted on a 


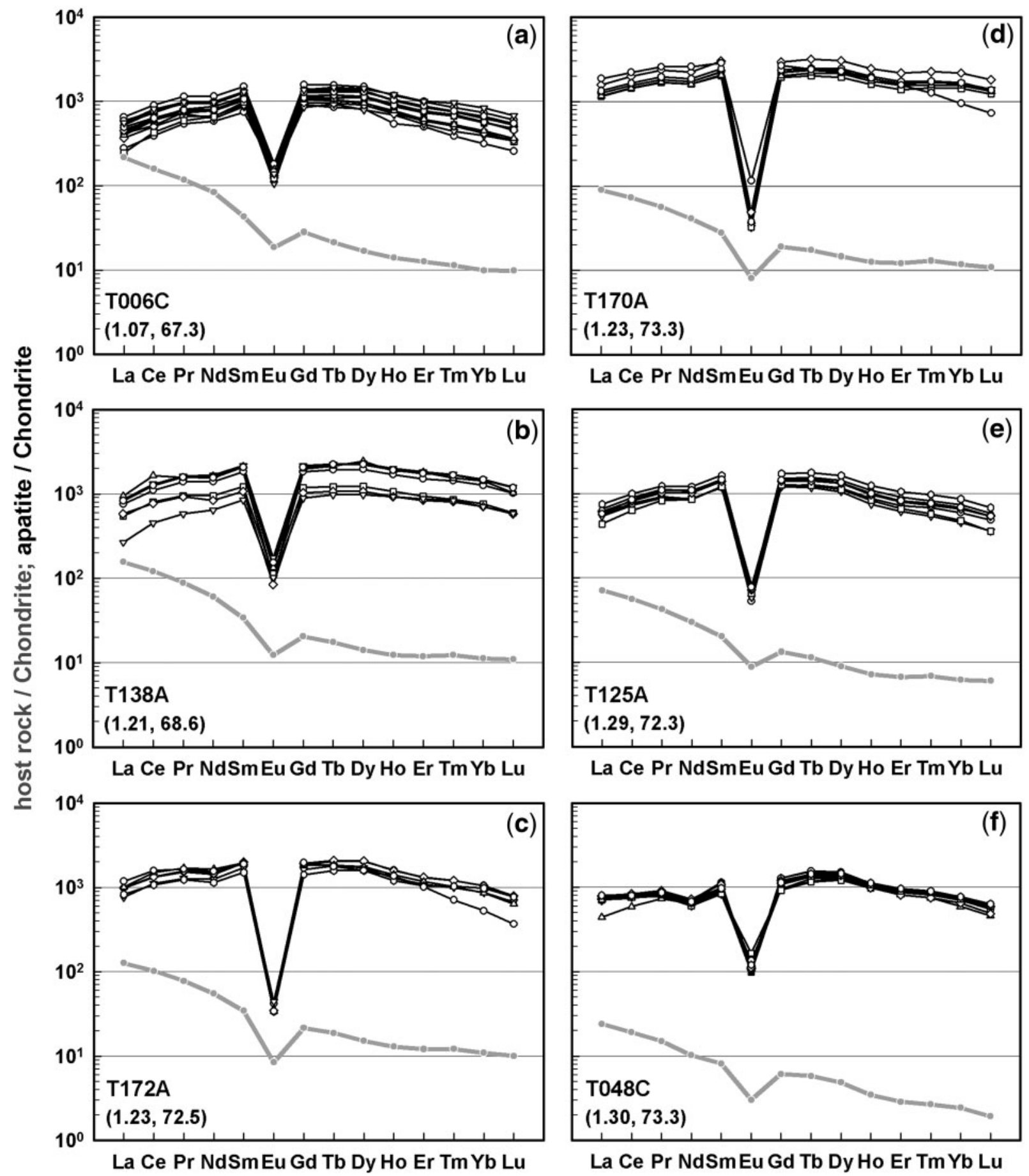

Fig. 11. Chondrite-normalized REE patterns of apatites (black lines with open symbols) and their host-rocks, Transhimalayan S-type granites (light grey lines with filled symbols); ASI and silica content of the bulk-rock are given in parentheses for reference.

logarithmic scale. There is a simple method to check whether the Nd depletion in apatite can be inherited from its host magma or is due to competition with monazite. The possibility of control by the host magma composition is negated if, after normalization to the bulk-rock, the
REE patterns of apatites still show significant Nd depletion. However, if the bulk-rock-normalized apatite REE patterns show only a small $\mathrm{Nd}$ depletion, or none, the alternative explanation is confirmed; that is, that the $\mathrm{Nd}$ depletion in the apatite REE patterns originates from the 


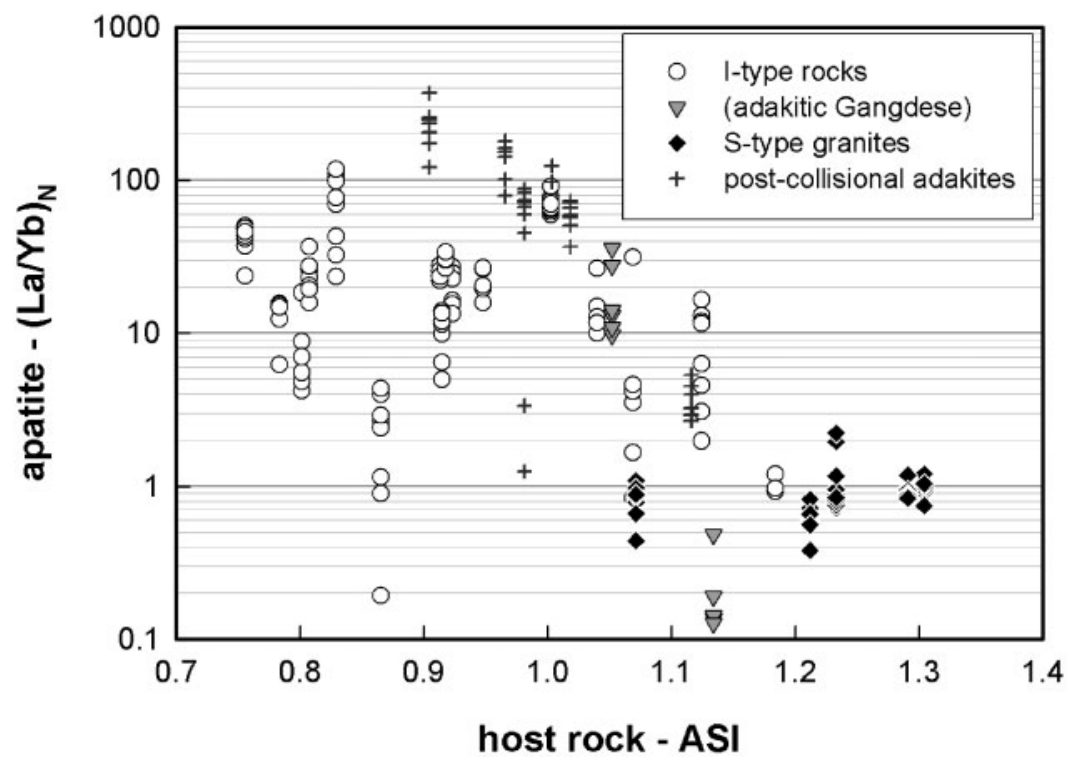

Fig. 12. Correlation between chondrite-normalized La/Yb ratios in apatites and ASI of their host-rocks.

geochemistry of the host magma. The latter case is clearly demonstrated by our data (Fig. 14).

Monazite strongly favors Th over $\mathrm{U}$, and its crystallization will result in a marked decrease in Th contents and $\mathrm{Th} / \mathrm{U}$ in the residual magma. This should produce a positive correlation between the depletion of $\mathrm{Nd}$ in the REE patterns and the $\mathrm{Th} / \mathrm{U}$ of apatite. However, this correlation is not obvious in apatites from (peraluminous) S-type granites. The main accessory minerals in peraluminous magmas are apatite + zircon \pm allanite \pm monazite \pm titanite \pm xenotime. Of these, zircon is the only common liquidus phase in magmas that has a much higher preference for $\mathrm{U}$ than for Th (Electronic Appendix Table 5d). Fractionation of zircon could compensate for the variation of $\mathrm{Th} / \mathrm{U}$ in the magma produced by monazite crystallization, and thus cause the observed lack of correlation between $\mathrm{Th} / \mathrm{U}$ and $\mathrm{Nd}$ anomalies in apatites. However, $\mathrm{U}-\mathrm{Pb}$ dating shows that zircon in the Transhimalayan Stype granites is mostly inherited, and thus that zircon rarely crystallized from the S-type magmas (see Chu et al., 2006). Xenotime could be another potential candidate. However, it is not a ubiquitous mineral phase, and the poor understanding of its mineral-melt partition coefficients and the large ranges of $\mathrm{Th}$ and $\mathrm{U}$ in xenotime (Förster, 1998) make it difficult to assess the effects of its crystallization.

These inconsistencies might be explained if the apatites in the S-type granites, like their zircons, are inherited; however, the origin of the negative $\mathrm{Nd}$ anomalies is still difficult to explain. For fractionation of a mineral to produce a negative $\mathrm{Nd}$ anomaly in apatite, its $\mathrm{Nd}$ partition coefficient would need to be distinctly greater than those for Pr and Sm. However, partition coefficients of REE in monazite and other minerals typically vary as a smooth function of their continuously varying ionic radius. Thus the strong fractionation of monazite, with the highest partition coefficients around $\mathrm{Nd}$, can result in a trough-like REE pattern around $\mathrm{Nd}$, similar to examples shown by Yurimoto et al. (1990), but not a distinct kink at Nd as observed in the REE patterns of apatite.

Indeed, apatites with $\mathrm{Nd}$ depletion in chondritenormalized REE patterns also tend to show a broad negative anomaly around Ho and Er (e.g. Figs 9p and q, and 11); both are essential features of the so-called 'tetrad effect' (see Jahn et al., 2001). The tetrad effect reflects nonCHARAC (CHarge-And-RAdius-Controlled) geochemistry specifically in highly evolved magmas (Bau, 1996), where the behavior of high field strength elements (HFSE) including the REE is controlled by both electron configuration and complexing ligand types, and cannot be modeled by partition coefficients that vary as smooth functions of ionic radius. This phenomenon originates from the electronic repulsion attributed to the formation of various ligands between HFSE and volatiles such as $\mathrm{H}_{2} \mathrm{O}, \mathrm{Li}, \mathrm{B}, \mathrm{F}$ and/or $\mathrm{Cl}$, which are enriched in the magma. As a result of the tetrad effect, the bulk-rock and its mineral phases, including apatite and monazite (Irber, 1999), have REE patterns comprising four convex subpatterns in the subdivisions of La to $\mathrm{Nd}, \mathrm{Pm}$ to $\mathrm{Gd}, \mathrm{Gd}$ to Ho and Er to Lu. The tetrad effect and other nonCHARAC features, such as non-chondritic ratios of $\mathrm{Y} / \mathrm{Ho}$ and $\mathrm{Zr} / \mathrm{Hf}$, are mostly recognized in highly differentiated granites with strong hydrothermal interaction, such as some of the Transhimalayan S-type and highly evolved I-type granites. 

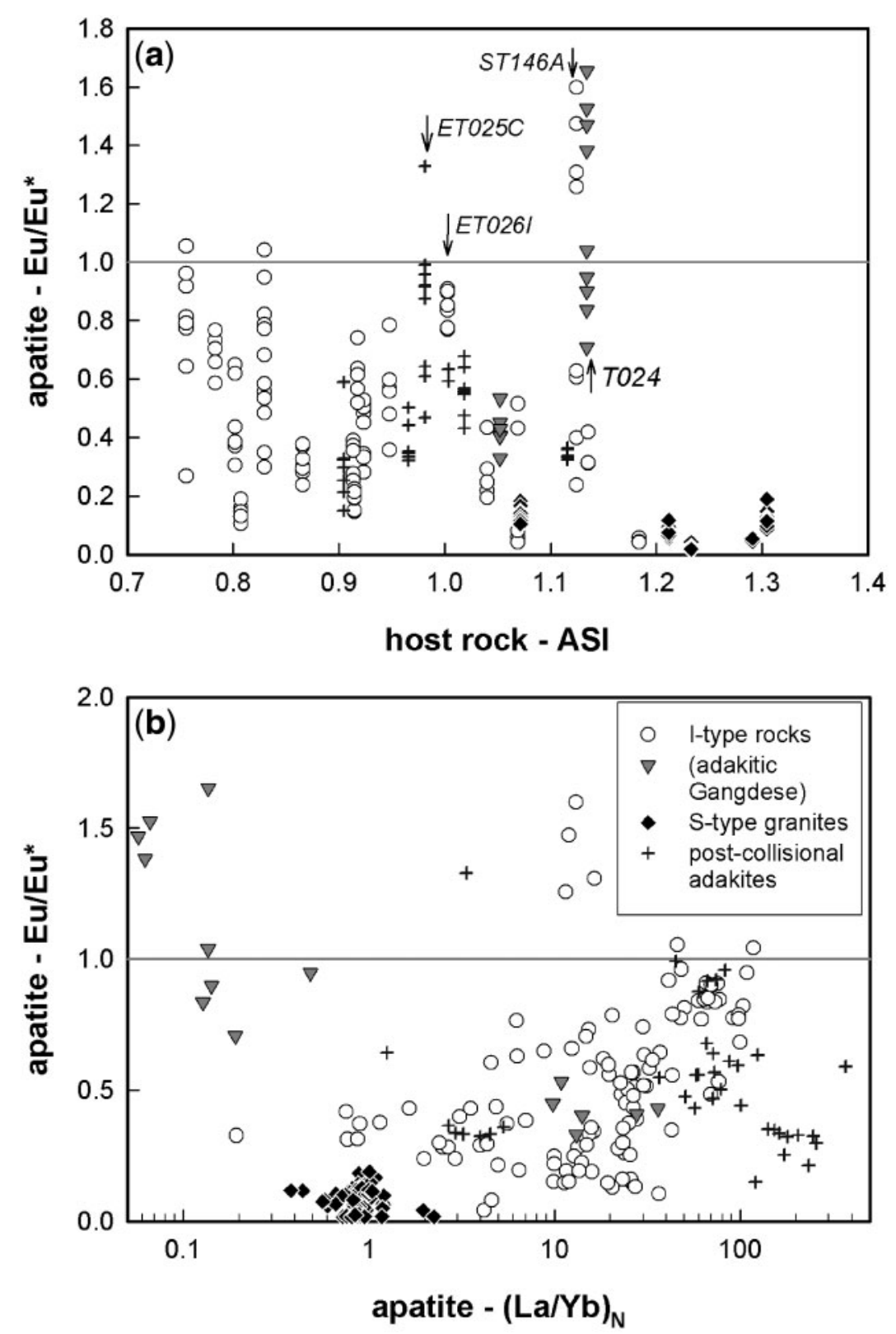

Fig. 13. Apatite Eu anomalies $\left(\mathrm{Eu} / \mathrm{Eu}^{*}\right)$ vs $(\mathrm{a})$ host-rock $\mathrm{ASI}$ and (b) apatite chondrite-normalized La/Yb ratios; $\mathrm{Eu}^{*}{ }_{\mathrm{N}}=(1 / 2) \mathrm{Sm}_{\mathrm{N}}+(1 / 2) \mathrm{Gd}_{\mathrm{N}}$.

\section{Effects of major minerals in mafic magmas}

Crystallization of major minerals can affect both the REE abundances and patterns of apatite; this effect is particularly pronounced in some mafic rocks of the I-type Gangdese magmatic suite; for example, T044E (Fig. 9a), T036C (Fig. 9c) and ST147A (Fig. 9f). Apatites in these rocks show large variations in REE. We suggest that apatite crystallized earlier in these mafic magmas tends to show (1) the most marked LREE enrichment, with high (La/ $\mathrm{Nd})_{\mathrm{N}}$ (e.g. $>4$ ), (2) the least $\mathrm{Eu}$ depletion, and (3) $\mathrm{Sr}$ contents similar to those of the bulk-rock. Such strongly LREE-enriched apatite always shows no (or weak) negative Eu anomaly. This corresponds to the least amount of fractionation of feldspars from the host melt and accordingly the least magmatic differentiation.

The crystallization of LREE-rich and/or Eu- and Sr-rich minerals such as titanite and plagioclase before or together with apatite can significantly reduce the LREE enrichment in apatite, and produce both negative anomalies in $\mathrm{Eu}$ and lower $\mathrm{Sr}$ abundances. Titanite $\left(\mathrm{CaTiSiO}_{5}\right)$ is one candidate because (1) its REE partition coefficients are 

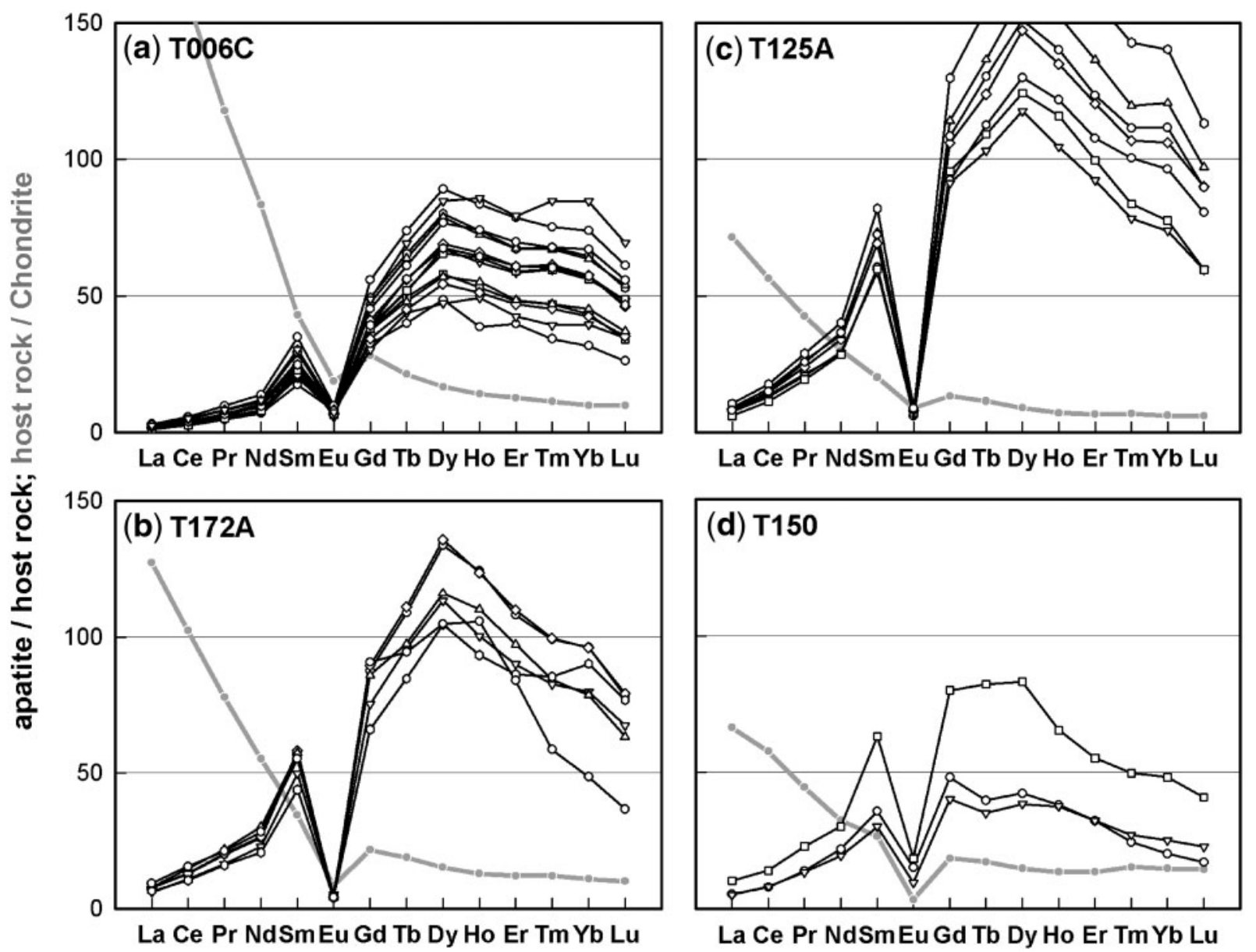

(d) T150

Fig. 14. Host rock-normalized REE patterns of apatites (black lines with open symbols) and chondrite-normalized REE patterns of their hostrocks (light grey lines with filled symbols); that is, some examples of S-type granites and evolved I-type peraluminous granites.

similar to those of apatite (Electronic Appendix Table 5c) and it concentrates LREE, and (2) it can precipitate from oxidized mafic magmas, although it usually crystallizes later than apatite in the Lachlan Fold Belt granites (Sha \& Chappell, 1999). Once crystallization of titanite becomes important in the magma, the LREE enrichment of apatites crystallized later or synchronously becomes smaller.

In metaluminous Gangdese rocks, as the slopes of the LREE patterns of the apatites become less steep, their negative $\mathrm{Eu}$ anomalies generally deepen, especially in the more mafic rocks (Fig. 15). This effect can be produced by crystallization of plagioclase concurrent with or before apatite. In mafic magmas, only the crystallization of plagioclase can deplete $\mathrm{Eu}$ by selectively extracting $\mathrm{Eu}^{2+}$ (see Table 1), and plagioclase is the major rock-forming mineral in these rocks that prefers the LREE to the HREE (e.g. Dunn \& Sen, 1994: $D_{\mathrm{La}}=0.075-0 \cdot 18, D_{\mathrm{Ce}}=0 \cdot 062-0 \cdot 14$, $D_{\mathrm{Eu}}=0.48-0.79, D_{\mathrm{Gd}}=0.016-0.067$, and $D_{\mathrm{Yb}}=0.004-$ 0.014 for plagioclase in basaltic to andesitic arc magmas), although its partition coefficients $(D)$ for the LREE are less than unity. Amphibole and pyroxene can also fractionate the REE, but these are not major phases.

We assume that only apatite and plagioclase compete for the REE in the mafic magmas, as apatite is the only common early crystallized accessory phase that can concentrate the REE (Hoskin et al., 2000). In the literature, apatite partition coefficients for basic and intermediate magmas vary widely (e.g. $D_{\mathrm{La}}=2 \cdot 5-28 \cdot 2$; Electronic Appendix Table 4). The ability of apatite to concentrate La, for example, can be 15-380 times that of plagioclase. Nevertheless, the modal abundance of plagioclase typically is a few hundred times that of apatite in mafic intrusive rocks.

Mass-balance considerations suggest that crystallization of both accessory minerals and rock-forming minerals can cause subtle changes in apatite REE patterns within a single magma chamber. Plagioclase also preferentially concentrates Sr. Although apatite has a Sr partition coefficient of more than unity $(1 \cdot 1$ to $\leq 8$; Electronic Appendix Table 4), comparable with that of feldspar, the Sr content 


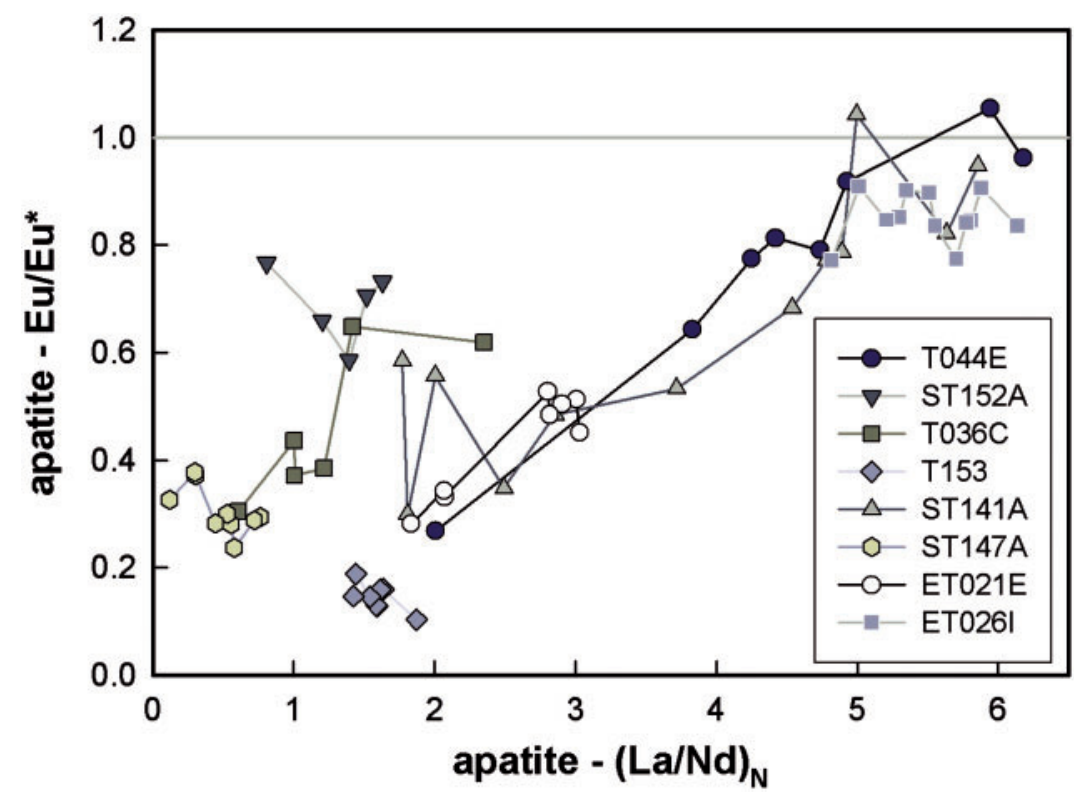

Fig. 15. Correlation between Eu anomaly and chondrite-normalized $\mathrm{La} / \mathrm{Nd}$ ratios, representing the degree of LREE enrichment of apatites in I-type Gangdese mafic rocks and ET026I, an isaluminous I-type granite.

of apatite is mostly lower than that of its host magma after competition with abundant plagioclase (Fig. 5a).

Apatites that crystallized earlier than plagioclase have lower HREE contents (down to $<10$ times the contents of the bulk-rock) and upward-concave REE patterns. Because the highest partition coefficients for apatite are around $\mathrm{Sm}, \mathrm{Gd}$ or $\mathrm{Tb}$ in mafic magmas (Electronic Appendix Table 4), this can be attributed to the fractionation of pyroxene and amphibole, which are HREEenriched. In summary, apatite in these mafic magmas started to crystallize later than pyroxene and/or amphibole, but together with, or a little earlier than, plagioclase. This demonstrates that the REE and Sr contents of apatite can be used as tracers for magmatic processes, and apatite has the ability to retain information on the geochemical evolution of the host magma.

\section{Indicators of petrogenesis}

The Sr contents, REE patterns and Eu anomalies of apatite are related to the geochemical composition of its host magma, and thus they have high potential as indicators of magma mixing and/or compositional heterogeneity in the magma source region. The peculiar behavior of these indicators in apatites from ET025C (a metaluminous adakite; Fig. 8c), ET026I (an isaluminous I-type granite; Fig. 9l), ST146A (a peraluminous I-type granite; Fig. 9o), and T027 (an I-type peraluminous adakitic granite; Fig. 10a) provides examples. These apatites share some of the following characteristics: (1) a positive Eu anomaly inconsistent with that of the host-rock; (2) higher Sr abundances than their host-rocks or widely variable Sr abundances; (3) REE patterns inconsistent with the host-rock aluminosity.

Apatite REE patterns commonly exhibit negative (or no) Eu anomalies, reflecting both the redox state of the host melt and particularly the fractionation of feldspar (alkali felspar and plagioclase) and of epidote to some degree (Bea, 1996). Positive Eu anomalies in apatites cannot be produced by fractionation processes, but reflect a magma source with a positive Eu anomaly. In some apatites in sample ST146A, for example, the Eu peaks in the REE patterns show that these apatites crystallized in a magma with a positive Eu anomaly, but the bulk magma of ST146 shows mild Eu depletion (Fig. 9o). The inconsistent positive Eu anomalies in the apatites strongly suggest that at least two magmas or magma sources were involved. One, from which most of the apatites with negative Eu anomalies crystallized, was peraluminous with a composition more like the bulk-rock of ST146. The other has an ASI less than 1.1, with a positive Eu anomaly, suggesting that the source of this magma essentially consisted of feldspar cumulates.

The Sr contents of apatites are analogues of the magma from which they crystallized. Commonly, apatite contains less $\mathrm{Sr}$ than its host-rock and shows limited ranges in $\mathrm{Sr}$ concentration (less than 200 ppm; Fig. 5a). Some of the apatite grains in T027, ET026I and ET025C have much higher Sr contents than the values expected from their whole-rock ASI or Sr contents, and they also show a range in $\mathrm{Sr}$ abundance of $>400 \mathrm{ppm}$ (Fig. 5a). During the formation of these three samples, magmas with much 

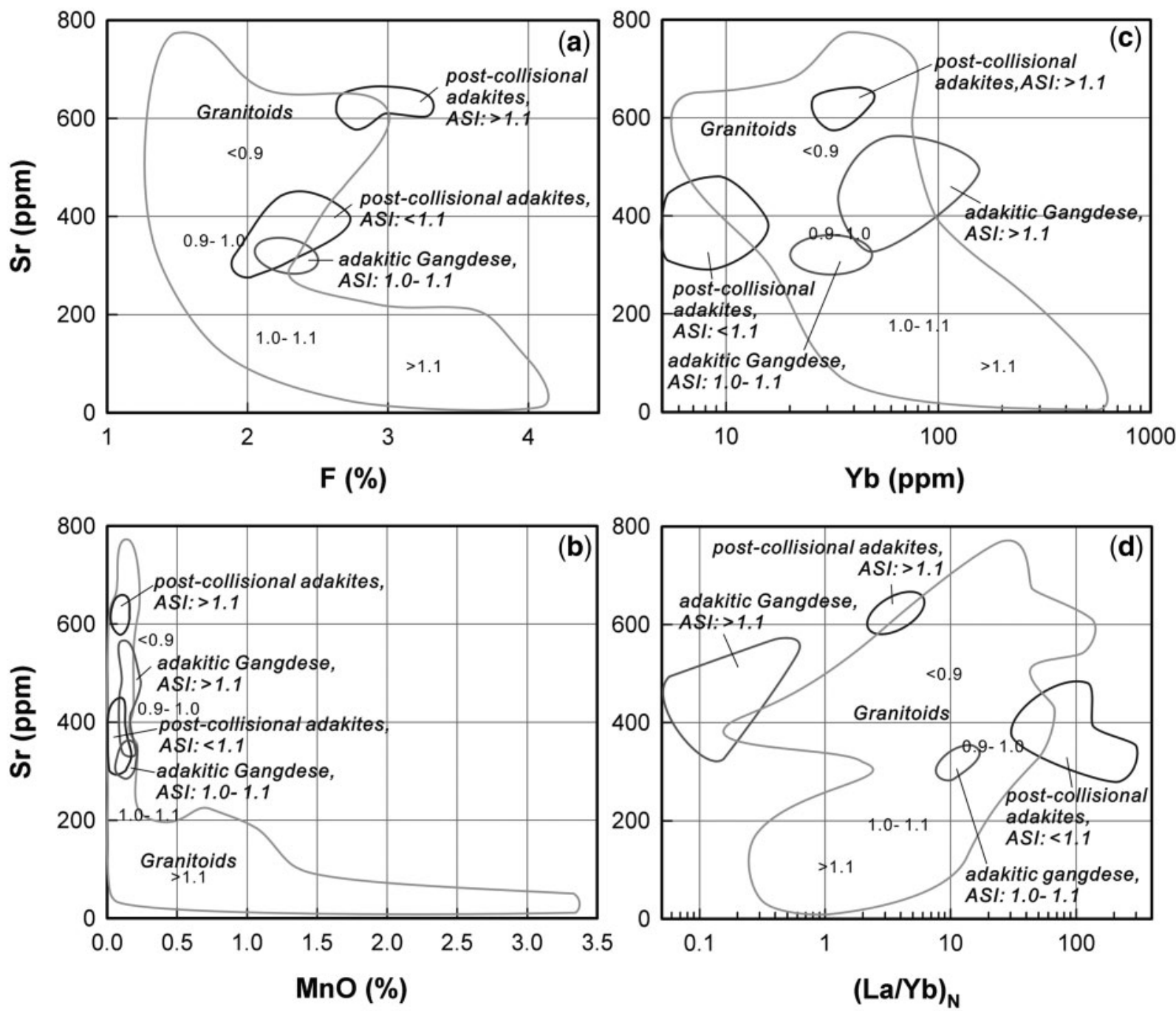

Fig. 16. Minor and trace element discrimination plots for apatite from Transhimalayan intrusive rocks with variable aluminosity. Corresponding aluminosity of the granitoids is shown by numbers.

higher Sr contents than the final bulk-rock must have existed in the magma chamber or the magma source. Because the Sr abundances of magmas decrease with fractional crystallization, such magmas were probably more mafic than the final bulk-rock composition (Fig. 5b). Values of $\left(\mathrm{Sr}_{\text {apatite }} / \mathrm{Sr}_{\text {bulk-rock }}\right)>1$ are therefore suggested as an indicator that a more mafic magma was involved in magma genesis. The observed correlations between apatite Sr contents and some host-rock major and trace elements (e.g. Fig. 5b) make it possible to identify the geochemistry of the possible end-member magma.

Zircons in T027 and ET026I were analysed for their Hf isotopic compositions; the results display pronounced variation in, and correlation between, trace-element abundances and ratios $\left[\right.$ e.g. $\left.{ }^{176} \mathrm{Yb} /{ }^{177} \mathrm{Hf}(0 \cdot 01-0 \cdot 07)\right]$ and $\mathrm{Hf}$ isotope compositions which vary over 10 epsilon-units (Chu, 2006; see Electronic Appendix Fig. 2). These data suggest that at least two magmas with different isotopic and trace-element signatures mixed during the formation of samples T027 and ET026I.

Although sample ET026I has a whole-rock ASI $=1 \cdot 0$, its apatite has an inconsistent, steep LREE-enriched REE pattern with no $\mathrm{Eu}$ anomaly, similar to those in mafic rocks such as T044E, ST141A and T036C (Fig. 9a, c and e). These apatites also have higher Sr concentrations than their host-rock. The geochemical characteristics of the ET026I apatites therefore suggest that they originated in a much less evolved magma. Either magma mixing or source heterogeneity can be responsible for these inconsistent apatite REE patterns.

Apatite in ET025C, a metaluminous adakite, would be expected to have a strongly LREE-enriched REE pattern, based on the general trend of REE variation vs ASI. However, ET025C contains some apatite grains with flat 

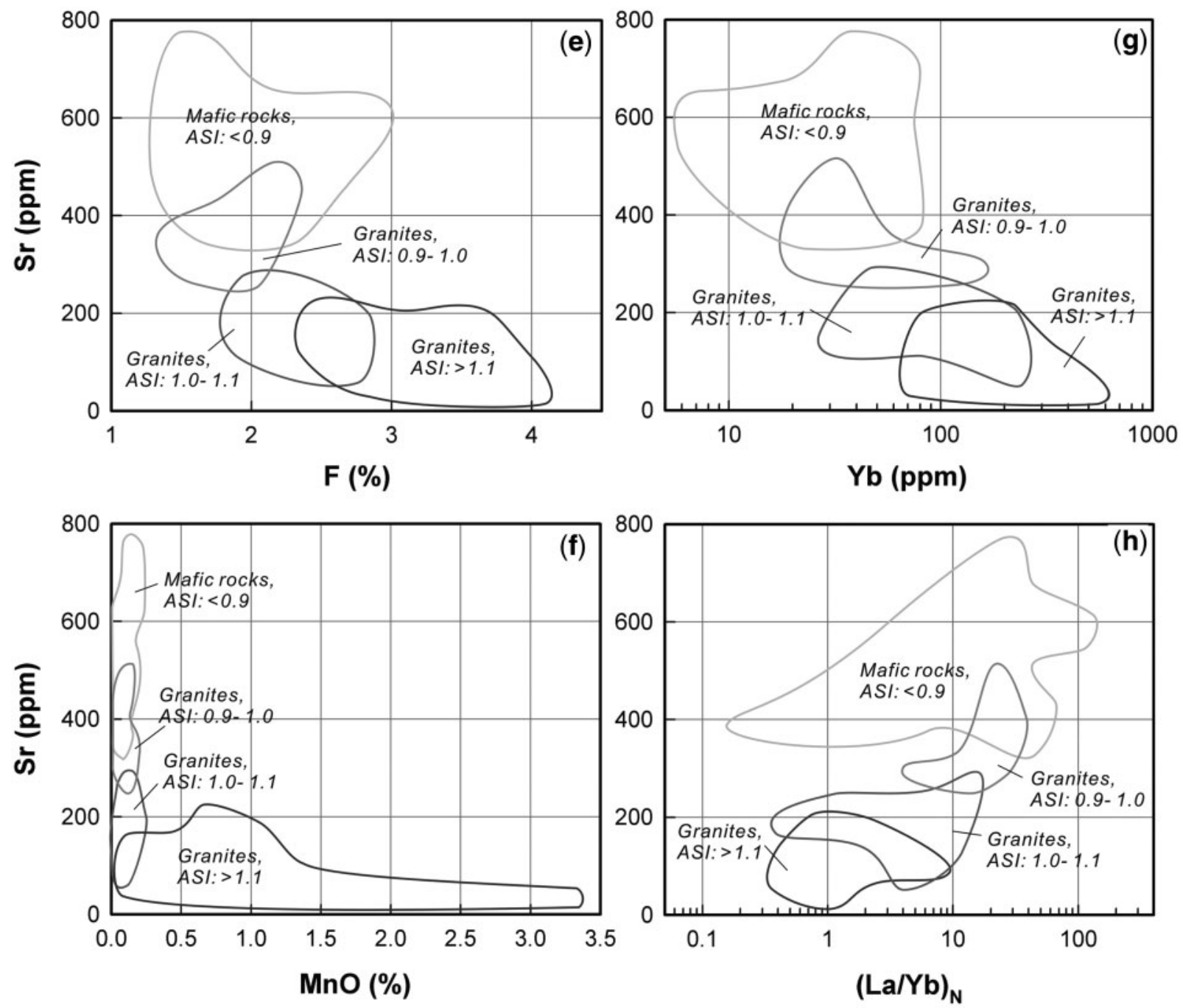

Fig. 16. Continued.

REE patterns (Fig. 8c) and no transitional patterns are observed. These apatites may be (1) inherited from the magma source, (2) crystallized from an evolved adakitic magma after differentiation, or (3) derived through wallrock contamination by the (peraluminous) crust of the Lhasa terrane. If a peraluminous adakitic magma had evolved through magma mixing or fractional crystallization, the newly forming apatites should have characteristics similar to those in T016 with mild LREE enrichment. In addition, although the source rocks of the adakite magma may contain apatite with flat REE patterns (Bea \& Montero, 1999), high Sr contents in apatite are also expected. This is not the case in ET025C; however, a small degree of wall-rock contamination, which would not significantly modify the bulk-magma REE pattern, can reasonably explain the presence of two types of apatite REE patterns.

\section{Provenance discrimination}

In the Transhimalayan intrusive rocks, apatite geochemistry is more strongly controlled by whole-rock aluminosity (ASI) than by silica content. Systematic variations in the minor- and trace-element composition of apatite relative to host-rock ASI are observed, especially in F, Mn, Sr and REE contents and chondrite-normalized REE patterns, including the LREE/HREE ratio, Eu anomaly and $\mathrm{Nd}$ anomaly (Table 2). The behaviour of $\mathrm{F}$ and $\mathrm{Mn}$ in apatites is associated with magmatic differentiation or aluminosity and independent of rock type, whereas that of $\mathrm{Sr}$ and REE varies with both aluminosity and rock type.

Mn, Sr and REE were suggested as discriminants based on the statistical analysis approach of Belousova et al. (2002), although adakites were not included in their database. The abundances of these elements and $\mathrm{F}$ in Transhimalayan apatites show variations comparable with 
those observed by Sha \& Chappell (1999). These studies also demonstrate the potential of the abundances of $\mathrm{F}$, $\mathrm{Mn}, \mathrm{Sr}$ and REE as provenance indicators in detrital apatite. After rejecting those apatite data that are not representative of their host-rock composition, the geochemical data for apatite in Transhimalayan rocks have been used to generate discrimination plots, distinguishing apatites from I-type mafic rocks, I-type granites, and S-type granites (Fig. 16). Where apatite compositions in these rock types plot far from the recommended fields in Fig. 16, magma mixing or source heterogeneity may be involved, and this emphasizes the need to evaluate the data by population; single grains may give misleading results.

Apatites in peraluminous I-type and S-type rocks, particularly those with ASI $>1 \cdot 1$, have similar geochemistry in terms of major, minor and trace elements, and typically flat REE patterns. This makes it difficult to distinguish between peraluminous I-type and S-type rocks using apatite geochemistry. If in situ $\mathrm{Sr}$ or $\mathrm{Nd}$ isotope compositions of apatites can be measured, better constraints on the petrogenesis might be obtained.

\section{GONGLUDING REMARKS}

The aluminosity (ASI) of the host magma is a critical control on the geochemical behavior of apatite in Transhimalayan plutonic rocks. This is consistent with the observations of Bea (1996), Sha \& Chappell (1999) and Hsieh et al. (2008). Abundances of trace elements in Transhimalayan apatites vary not only with the aluminosity of the host magma, but also more specifically with rock type. The composition of apatite shows significant variation between metaluminous and peraluminous magmas, and between rock types, particularly in terms of F, Mn, Sr and REE contents, demonstrating the potential of apatite geochemistry as a petrogenetic tracer.

The behavior of minor elements, including $\mathrm{F}$ and $\mathrm{Mn}$, in Transhimalayan apatites is independent of the host magma type; that is, I-type intrusions, S-type granites and adakites. F contents in apatite increase with host-rock aluminosity. Mn contents rise with increasing aluminosity of the peraluminous host-rock. Accordingly, $\mathrm{F}$ and $\mathrm{Mn}$ contents of apatites carry specific information about magma aluminosity or fractionation.

Sr concentrations in apatites mimic those of the host magmas, and in general are lower than those of host magma with restricted ranges of $<200 \mathrm{ppm}$. Apatite $\mathrm{Sr}$ contents can be used to discriminate between host-rock types; the Sr content of apatite in adakites is substantially higher for a given host-rock aluminosity or a given Fabundance in the apatite itself, and the value is comparable with that in I-type mafic rocks. Significantly larger ranges in Sr content, and apatite $\mathrm{Sr}$ contents higher than their host-rock, may indicate that these apatites crystallized in magmas of different trace-element composition from the bulk-rock, and signal the effects of magma mixing.

The REE patterns of apatite show potential in petrogenetic applications. The patterns normally vary from strongly LREE-enriched to flat, reflecting the crystallization of competing rock-forming and accessory minerals, producing depletion in Eu and even $\mathrm{Nd}$. They also can be modified by specific magma compositions; for instance, the HREE-depleted characteristics of apatites from adakites. When apatite shows REE patterns and/or positive Eu anomalies that are inconsistent with the host-rock aluminosity and Eu depletion, this implies the effects of magma mixing, crustal contamination or source heterogeneity in the generation of the magma.

\section{ACKNOWLEDGEMENTS}

This study benefited from financial support by the National Science Council, Taiwan. We thank J. Q. Ji (School of Earth and Space Sciences, Peking University), H.-Y. Lee (National Taiwan University), Q. Qian (Institute of Geology and Geophysics, Chinese Academy of Sciences), D.-R. Wen (National Taiwan University) and Q. Zhang (Institute of Geology and Geophysics, Chinese Academy of Sciences) for help with fieldwork. Fernando Bea, Julian A. Pearce and two anonymous reviewers are thanked for their positive and constructive comments. Analytical data were obtained at GEMOC using instrumentation funded by ARG LIEF, and DEST Systemic Infrastructure Grants and Macquarie University. This is contribution 609 from the ARG National Key Centre for the Geochemical Evolution and Metallogeny of Continents (www.es.mq.edu.au/GEMOC).

\section{SUPPLEMENTARY DATA}

Supplementary data for this paper are available at fournal of Petrology online.

\section{REFERENGES}

Allègre, C. J., Courtillot, V., Tapponnier, P. et al. (1984). Structure and evolution of the Himalaya-Tibet orogenic belt. Nature 307, 17-22.

Bau, M. (1996). Controls on the fractionation of isovalent trace elements in magmatic and aqueous systems: evidence from $\mathrm{Y} / \mathrm{Ho}, \mathrm{Zr} /$ Hf, and lanthanide tetrad effect. Contributions to Mineralogy and Petrology 123, 323-333.

Bea, F. (1996). Residence of REE, Y, Th and U in granites and crustal ptotoliths; implications for the chemistry of crustal melts. Fournal of Petrology 37, 521-552.

Bea, F. \& Montero, P. (1999). Behavior of accessory phases and redistribution of Zr, REE, Y, Th, and U during metamorphism and partial melting of metapelites in the lower crust: an example from the Kinzigite Formation of Ivrea-Verbano, NW Italy. Geochimica et Cosmochimica Acta 63, 1133-1153.

Belousova, E. A., Walters, S., Griffin, W. L. \& O'Reilly, S. Y. (2001). Trace-element signatures of apatites in granitoids from the Mt Isa 
Inlier, northwestern Queensland. Australian fournal of Earth Sciences 48, 603-619.

Belousova, E. A., Griffin, W. L., O’Reilly, S. Y. \& Fisher, N. I. (2002). Apatites as an indicator mineral for mineral exploration: trace-element compositions and their relationship to host rock type. Fournal of Geochemical Exploration 76, 45-69.

Belousova, E. A., Griffin, W. L. \& O’Reilly, S. Y. (2006). Zircon morphology, trace element signatures and Hf-isotope composition as a tool for petrogenetic modeling: examples from Eastern Australian granitoids. Fournal of Petrology 47, 329-353.

Bizzarro, M., Simonetti, A., Stevenson, R. K. \& Kurszlaukis, S. (2003). In situ ${ }^{87} \mathrm{Sr} /{ }^{86} \mathrm{Sr}$ investigation of igneous apatites and carbonates using laser-ablation MC-ICP-MS. Geochimica et Cosmochimica Acta 67, 289-302.

Chu, M.-F. (2006). Application of ICP-MS to the study of Transhimalayan petrogenesis. $\mathrm{PhD}$ Thesis, National Taiwan University, Taipei.

Chu, M.-F., Chung, S.-L., Song, B., Liu, D., O'Reilly, S. Y., Pearson, N. J., Ji, J. \& Wen, D.-J. (2006). Zircon U-Pb and Hf isotope constraints on the Mesozoic tectonics and crustal evolution of southern Tibet. Geology 34, 745-748.

Chung, S.-L., Liu, D., Ji, J., Chu, M.-F., Lee, H.-Y., Wen, D.-J., Lo, C.H., Lee, T.-Y., Qian, Q. \& Zhang, Q. (2003). Adakites from continental collision zone: melting of thickened lower crust beneath southern Tibet. Geology 31, 1021-1024.

Chung, S.-L., Chu, M.-F., Zhang, Y., Xie, Y., Lo, C.-H., Lee, T.-Y., Lan, C.-Y., Li, X., Zhang, Q. \& Wang, Y. (2005). Tibetan tectonic evolution inferred from spatial and temporal variations in post-collisional magmatism. Earth-Science Reviewes 68, 173-196.

Coulon, C., Maluski, H., Bollinger, C. \& Wang, S. (1986). Mesozoic and Cenozoic volcanic rocks from central and southern Tibet: ${ }^{39} \mathrm{Ar}-{ }^{40} \mathrm{Ar}$ dating, petrological characteristics and geodynamical significance. Earth and Planetary Science Letters 79, 281-302.

Debon, F., Le Fort, P., Sheppard, S. M. F. \& Sonet, J. (1986). The four plutonic belts of the trans-Himalaya: a chemical, mineralogical, isotopic and chronological synthesis along a Tibet-Nepal section. Fournal of Petrology 27, 219-250.

Dunn, T. \& Sen, C. (1994). Mineral/matrix partition coefficients for orthopyroxene, plagioclase, and olivine in basaltic to andesitic systems: a combined analytical and experimental study. Geochimica et Cosmochimica Acta 58, 717-733.

Eggins, S. M. \& Shelley, J. M. G. (2002). Compositional heterogeneity in NIST SRM 610-617 Glasses. Geostandards Nerwsletter 26, 269-286.

Förster, H.-J. (1998). The chemical composition of REE-Y-Th-U-rich accessory minerals in peraluminous granites of the ErzgebirgeFichtelgebirge region, Germany. Part II: Xenotime. American Mineralogist 83, 1302-1315.

Griffin, W. L., Pearson, N. J., Belousova, E., Jackson, S. E., van Achterbergh, E., O'Reilly, S. Y. \& Shee, S. R. (2000). The Hf isotope composition of cratonic mantle: LAM-MC-ICPMS analysis of zircon megacrysts in kimberlites. Geochimica et Cosmochimica Acta 64, 133-147.

Griffin, W. L., Wang, X., Jackson, S. E., Pearson, N. J., O’Reilly, S. Y., $\mathrm{Xu}, \mathrm{X}$. \& Zhou, X. (2002). Zircon chemistry and magma mixing, SE China: in-situ analysis of Hf isotopes, Tonglu and Pingtan igneous complexes. Lithos 61, 237-269.

Griffin, W. L., Powell, W. J., Pearson, N. J. \& O'Reilly, S. Y. (2008). GLITTER: Data reduction software for laser ablation ICP-MS (appendix). In: Sylvester, P. (ed.) Laser Ablation-ICP-MS in the Earth Sciences. Mineralogical Association of Canada (MAC), Short Course Series 40, 308-311.

Günther, D., Jackson, S. E. \& Longerich, H. P. (1999). Laser ablation and arc/spark solid sample introduction into inductively coupled plasma mass spectrometers. Spectrochimica Acta Part B: Atomic Spectroscopy 54, 381-409.

Harris, N. B. W., Inger, S. \& Xu, R. (1990). Cretaceous plutonism in Central Tibet: An example of post-collision magmatism? Fournal of Volcanology and Geothermal Research 44, 21-32.

Hawkesworth, C. J. \& Kemp, A. I. S. (2006). Using hafnium and oxygen isotopes in zircons to unravel the record of crustal evolution. Chemical Geology 266, 144-162.

Hoskin, P. W. O., Kinny, P. D., Wyborn, D. \& Chappell, B. W. (2000). Identifying accessory mineral saturation during differentiation in granitoids magmas: an integrated approach. Fournal of Petrology 41, 1365-1396

Hsieh, P.-S., Chen, C.-H., Yang, H.-J. \& Lee, C.-Y. (2008). Petrogenesis of the Nanling Mountains granites from South China: constraints from systematic apatite geochemistry and whole-rock geochemical and $\mathrm{Sr}-\mathrm{Nd}$ isotope compositions. Fournal of Asian Earth Sciences 33, 428-451.

Irber, W. (1999). The lanthanide tetrad effect and its correlation with $\mathrm{K} / \mathrm{Rb}, \mathrm{Eu} / \mathrm{Eu}^{*}, \mathrm{Sr} / \mathrm{Eu}, \mathrm{Y} / \mathrm{Ho}$, and $\mathrm{Zr} / \mathrm{Hf}$ of evolving peraluminous granite suites. Geochimica et Cosmochimica Acta 63, 489-508.

Jackson, S. E. (2001). The application of Nd:YAG lasers in LA-ICPMS. In: Sylvester, P. (ed.) Principles and Applications of Laser Ablation ICP-Mass Spectrometry in the Earth Sciences. Mineralogical Association of Canada (MAC), Short Course Series 29, 29-45.

Jahn, B. M., Wu, F., Capdevila, R., Martineau, F., Wang, Y. \& Zhao, Z. (2001). Highly evolved juvenile granites with tetrad REE patterns: the Woduhe and Baerzhe granites from the Great Xing'an (Khingan) Mountains in NE China. Lithos 59, 171-198.

Ji, W.-Q., Wu, F.-Y., Chung, S.-L., Li, J.-X. \& Liu, C.-Z. (2009). Zircon $\mathrm{U}-\mathrm{Pb}$ geochronology and $\mathrm{Hf}$ isotopic constraints on petrogenesis of the Gangdese batholith, southern Tibet. Chemical Geology 262, 229-245.

Kapp, P., Yin, A., Harrison, T. M. \& Ding, L. (2005). CretaceousTertiary shortening, basin development, and volcanism in central Tibet. Geological Society of America Bulletin 117, 865-878.

Kemp, A. I. S., Hawkesworth, C. J., Foster, G. L., Paterson, B. A., Woodhead, J. D., Hergt, J. M., Gray, C. M. \& Whitehouse, M. J. (2007). Magmatic and crustal differentiation history of granitic rocks from Hf-O isotopes in zircon. Science 315, 980-983.

Lee, H.-Y., Chung, S.-L., Wang, Y., Zhu, D. C., Yang, J. H., Song, B., Liu, D. \& Wu, F. Y. (2007). Age, petrogenesis and geological significance of the Linzizong volcanic successions in the Linzhou basin, southern Tibet: evidence form zircon $\mathrm{U}-\mathrm{Pb}$ and $\mathrm{Hf}$ isotopes (in Chinese, with English abstract). Acta Petrologica Sinica 23, 493-500.

Lee, H.-Y., Chung, S.-L., Lo, C.-H., Ji, J., Lee, T.-Y., Qian, Q. \& Zhang, Qi (2009). Eocene Neotethyan slab breakoff in southern Tibet inferred from the Linzizong volcanic record. Tectonophysics doi:10.1016/j.tecto.2009.02.031.

Molnar, P. \& Tapponnier, P. (1975). Cenozoic tectonics of Asia: effects of a continental collision: features of recent continental tectonics in Asia can be interpreted as results of the India-Eurasia collision. Science 189, 419-426.

Norman, M. D., Pearson, N. J., Sharma, A. \& Griffin, W. L. (1996). Quantitative analysis of trace elements in geological materials by laser ablation ICPMS: instrumental operating conditions and calibration values of NIST glasses. Geostandards Newsletter 20, 247-261.

Norman, M. D., Griffin, W. D., Pearson, N. J., Garciac, M. O. \& O'Reilly, S. Y. (1998). Quantitative analysis of trace element abundances in glasses and minerals: A comparison of laser ablation inductively coupled plasma mass spectrometry, solution inductively coupled plasma mass spectrometry, proton microprobe and electron microprobe data. Fournal of Analytical Atomic Spectrometry 13, $477-482$. 
Pan, G., Ding, J., Yao, D. \& Wang, L. (2004). Guide book of 1:1,500,000 geologic map of the Qinghai-Xizang (Tibet) plateau and adjacent areas. Chengdu, China: Chengdu Cartographic Publishing House.

Sano, Y., Oyama, T., Terada, K. \& Hidaka, H. (1999). Ion microprobe $\mathrm{U}-\mathrm{Pb}$ dating of apatite. Chemical Geology 153, 249-258.

Schärer, U., Corfu, F. \& Demaiffe, D. (1997). U-Pb and Lu-Hf isotopes in baddeleyite and zircon megacrysts from the Mbuji-Mayi kimberlite: constraints on the subcontinental mantle. Chemical Geology 143, 1-16.

Sha, L.-K. \& Chappell, B. W. (1999). Apatite chemical composition, determined by electron microprobe and laser-ablation inductively coupled plasma mass spectrometry, as a probe into granite petrogenesis. Geochimica et Cosmochimica Acta 63, 3861-3881.

Taylor, S. R. \& McLennan, S. M. (1985). The Continental Crust: its Composition and Evolution. Oxford: Blackwell Scientific Publications.

Valley, J. W. (2003). Oxygen isotopes in zircon. In: Hanchar, J. H. \& Hoskin, P. W. O. (eds) Zircon. Mineralogical Society of America, Reviews in Mineralogy and Geochemistry 53, 343-385.

Wen, D.-R. (2007). The Gangdese batholith, southern Tibet: ages, geochemical characteristics and petrogenesis. PhD Thesis, National Taiwan University, Taipei.

Wen, D.-R., Chung, S.-L., Song, B., Iizuka, Y., Yang, H.-J., Ji, J., Liu, D. \& Gallet, S. (2008a). Late Cretaceous Gangdese intrusions of adakitic geochemical characteristics, SE Tibet: petrogenesis and tectonic implications. Lithos doi:10.1016/j.lithos.2008.02.005.

Wen, D.-R., Liu, D., Chung, S.-L., Chu, M.-F., Ji, J., Zhang, Q, Song, B., Lee, T.-Y., Yeh, M.-W. \& Lo, C.-H. (2008b). Zircon SHRIMP $\mathrm{U}-\mathrm{Pb}$ ages of the Gangdese Batholith and implications for Neotethyan subduction in southern Tibet. Chemical Geology 252, 191-201.

Wilde, S. A., Valley, J. W., Peck, W. H. \& Graham, C. M. (2001). Evidence from detrital zircons for the existence of continental crust and oceans on the Earth 4.4 Gyr ago. Nature 409, 175-178.

Willigers, B. J. A., Baker, J. A., Krogstad, E. J. \& Peate, D. W. (2002). Precise and accurate in situ $\mathrm{Pb}-\mathrm{Pb}$ dating of apatite, monazite, and sphene by laser ablation multiple-collector ICP-MS. Geochimica et Cosmochimica Acta 66, 1051-1066.

Xu, R., Scharer, U. \& Allègre, C. J. (1985). Magmatism and metamorphism in the Lhasa Block (Tibet): a geochronological study. Fournal of Geology 93, 41-57.

Yin, A. \& Harrison, T. M. (2000). Geologic evolution of the Himalayan-Tibetan orogen. Annual Review of Earth and Planetary Sciences 28, 211-280.

Yurimoto, H., Duke, E. F., Papike, J. J. \& Shearer, C. K. (1990). Are discontinuous chondrite-normalized REE patterns in pegmatitic granite systems the results of monazite fractionation? Geochimica et Cosmochimica Acta 54, 2141-2145. 